\title{
Cold-seep-like macrofaunal communities in organic- and sulfide-rich sediments of the Congo deep-sea fan
}

\author{
Olu Karine ${ }^{1}$, Decker Carole ${ }^{1}$, Pastor Lucie ${ }^{1}$, Caprais Jean-Claude ${ }^{1}$, Khripounoff Alexis ${ }^{1}$, \\ Morineaux Marie ${ }^{1}$, Ain Baziz M. ${ }^{1}$, Menot Lenaick ${ }^{1}$, Rabouille C. ${ }^{2}$
}

${ }^{1}$ IFREMER Centre Bretagne, Laboratoire Environnement Profond, BP70, 20280 Plouzané, France

${ }^{2}$ Laboratoire des Sciences du Climat et de l'Environnement, Université Paris-Saclay, Gif sur Yvette, France

\begin{abstract}
:
Methane-rich fluids arising from organic matter diagenesis in deep sediment layers sustain chemosynthesis-based ecosystems along continental margins. This type of cold seep develops on pockmarks along the Congo margin, where fluids migrate from deep-buried paleo-channels of the Congo River, acting as reservoirs. Similar ecosystems based on shallow methane production occur in the terminal lobes of the present-day Congo deep-sea fan, which is supplied by huge quantities of primarily terrestrial material carried by turbiditic currents along the $800 \mathrm{~km}$ channel, and deposited at depths of up to nearly $5000 \mathrm{~m}$. In this paper, we explore the effect of this carbon enrichment of deepsea sediments on benthic macrofauna, along the prograding lobes fed by the current active channel, and on older lobes receiving less turbiditic inputs. Macrofaunal communities were sampled using either USNEL cores on the channel levees, or ROV blade cores in the chemosynthesis-based habitats patchily distributed in the active lobe complex.

The exceptionally high organic content of the surface sediment in the active lobe complex was correlated with unusual densitiesof macrofauna for this depth, enhanced by a factor 7 to 8 , compared with those of the older, abandoned lobe, whose sediment carbon content is still higher than in Angola Basin at same depth. Macrofaunal communities, dominated by cossurid polychaetes and tanaids were also more closely related to those colonizing low-flow cold seeps than those of typical deep-sea sediment. In reduced sediments, microbial mats and vesicomyid bivalve beds displayed macrofaunal community patterns that were similar to their cold-seep counterparts, with high densities, low diversity and dominance of sulfide-tolerant polychaetes and gastropods in the most sulfidic habitats. In addition, diversity was higher in vesicomyid bivalve beds, which appeared to bio-irrigate the upper sediment layers. High beta-diversity is underscored by the variability of geochemical gradients in vesicomyid assemblages, and by the vesicomyid population characteristics that vary in density, size and composition. By modifying the sediment geochemistry differently according to their morphology and physiology, the different vesicomyid species play an important role structuring macrofauna composition and vertical distribution. Dynamics of turbiditic deposits at a longer temporal scale (thousands of years) and their spatial distribution in the lobe area also resulted in high heterogeneity of the "cold-seep-like communities". Dynamics of chemosynthetic habitats and associated macrofauna in the active lobe area
\end{abstract}


resembled those previously observed at the Regab pockmark along the Congo margin and rapid succession is expected to cope with high physical disturbance by frequent turbiditic events and huge sedimentation rates. Finally, we propose a model of the temporal evolution of these peculiar habitats and communities on longer timescales in response to changes in distributary channels within the lobe complex.

Keywords: Chemosynthesis-based ecosystems, cold seeps, organic rich sediments, macrofaunal communities

\section{Introduction}

Chemosynthesis-based ecosystems sustained by fluid emissions enriched in reduced compounds are generally located in particular geological settings along continental margins (cold seeps) or oceanic ridges and back-arc basins (hydrothermal vents). At cold seeps, tectonic processes bring fluid and gas 


\section{ACCEPTED MANUSCRIPT}

to the seafloor from deep sedimentary layers where diagenesis has transformed organic matter into petroleum or lighter hydrocarbons such as methane. Fluid and gas are expelled through particular geological features such as pockmarks, mud volcanoes, diapirs or faults, and provide reduced compounds for chemosynthesis in a limited area on the seabed, generally covering no more than hundreds of square meters (Levin and Sibuet, 2012; Sibuet and Olu-Le Roy, 2002). Despite their relative stability (e.g. (Bergquist et al., 2003a), cold-seep emissions may cease due to carbonate precipitation after a few centuries (Bowden et al., 2013; Cordes et al., 2009) ultimately leading to colonization by non-chemosynthesis-based communities. Organic matter deposits - such as whale carcasses or sunken woods - also provide, very locally, large quantities of material and reduced compounds that can sustain chemosynthesis-based communities; however, these deposits are a limited and ephemeral resource lasting decades for large whale carcasses (Smith and Baco, 2003; Smith et al., 2002). Taxonomic similarities of the macrofaunal communities with those of cold seeps and hydrothermal vents evidenced taxonomic and evolutionary relationships between whale falls or sunken woods, seeps and vent fauna, suggesting the role of organic deposits as habitat providers and stepping stones for chemosynthetic fauna (Baco et al., 1999; Distel et al., 2000; Samadi et al., 2007; Smith et al., 1989), although recent network analysis based suggest that whale carcasses is not a significant stepping stone for vent or seep molluscs (Kiel et al. 2016). However, there are functional and faunal similarities between various habitats of the deep-sea floor, especially along continental margins, sustained by recent or much older accumulations of organic matter deposits in the sediments.

Continental margins indeed represent the "receptacles" of large quantities of organic matter, via enhanced primary production and terrestrial inputs, which are mainly transported through submarine canyons (e.g. (Heussner et al., 2006; Weaver et al., 2004). Benthic communities in canyons depend on a balance between enhanced food supply of terrestrial origin (Vetter et al., 2010) or cascades of enriched surface water (Rowe et al., 1982; Soltwedel et al., 2005), and disturbance due to tidal currents and periodic turbidity flows into the system (Khripounoff et al., 2003; Puig et al., 
2004). Although canyons are often reported as abundance hotspots (e.g. (De Leo et al., 2010; Heussner et al., 2006; Weaver et al., 2004), review by (Levin and Sibuet, 2012)), instability of the habitat may result in lower diversities than the communities inhabiting the adjacent abyssal plains, continental shelf and slopes (e.g. (Gage et al., 1995; Vetter and Dayton, 1998)). However, trapped macrophyte detritus (Vetter and Dayton, 1998), whale carcasses (Paull et al., 2010) or organic-rich layers and reducing sediments exposed by mass wasting and erosion of canyon walls (e.g. (Paull et al., 2010)) can also sustain chemosynthesis-based communities in canyons. Older organic matter accumulation in deep-buried turbiditic channels (paleo-channels) of the Congo River also act as reservoirs of methane-rich fluid expelled through present-day cold-seeps on pockmarks (Gay et al., 2007). One well-studied example is the Regab pockmark, which is densely populated with chemosynthesis-based communities (Olu-Le Roy et al., 2007; Ondréas et al., 2005), assumed to be supplied from biogenic processing of turbiditic deposits in a $300 \mathrm{~m}$ deep paleo-channel of the Congo River (Gay et al., 2006).

The present-day Congo channel with its terminal lobe complex is a unique case because it is directly connected to its terrestrial counterpart, the Congo River (Babonneau et al., 2002), whose freshwater discharge ranks second in the world (Milliman, 1991). Consequently, massive and direct transfer of particles is driven by strong turbidity currents within the canyon and channel (Khripounoff et al., 2003; Savoye et al., 2009; Savoye et al., 2000; Vangriesheim et al., 2005) that reach the terminal part of the deep-sea fan, $750 \mathrm{~km}$ away from the river mouth (Babonneau et al., 2002; Dennielou et al., in press. this isssue; Savoye et al., 2009; Vangriesheim et al., 2009). This results in exceptionally high sedimentation rates (up to $20 \mathrm{~cm} \cdot \mathrm{yr}^{-1}$ at some sites), high organic carbon content ( 3 to $5 \%$ wet weight) and high oxygen demand (Pozzato et al., subm. this issue; Rabouille et al., 2009; Stetten et al., 2015). The major part of the organic material is from terrestrial origin (Baudin et al., 2010; Baudin et al., in press b. this issue; Stetten et al., 2015; Treignier et al., 2006) . High turbidite frequency (about one event/decade, (Dennielou et al., in press. this isssue)) create an unstable environment, enhancing the impact of the huge sedimentation rates benthic fauna. A preliminary study of the 


\section{ACCEPTED MANUSCRIPT}

meiofaunal communities revealed extremely low densities, but the only core sampled came from the channel at the entrance of the lobe complex, assumed to be affected by high-velocity bottom currents and unstable sedimentary conditions (Van Gaever et al., 2009a). Macrofauna have been studied on the channel levees between 3000 and 4000 m depth (Galéron et al., 2009; Menot et al., 2010), but not in the terminal lobe area. Furthermore, the first ROV observations during geology dives in 2000 (ZaiRov cruise, (Savoye et al., 2000)) revealed the occurrence of white material resembling microbial mats, as well as large white shells - interpreted as vesicomyid bivalves - in a smooth and flat sedimentary area. These unexpected findings were confirmed 10 years later by ROV dives dedicated to the study of these chemosynthesis-based ecosystems (Rabouille et al., in press this issue). Although this area differ from a cold seep as not linked to fluid or gas migration from a deep reservoir by tectonic processes, lateral migration of methane in shallow sediment related to mass wasting has been evidenced (Croguennec et al., subm, this issue), and methane fluxes and geochemical gradients in sub-surface sediments are locally in the range of those found at seeps in similar habitats (Khripounoff et al., 2015; Pastor et al., in press, this issue). Two vesicomyid species described from cold-seeps were sampled in the area forming dense aggregates (Decker et al., in press this issue; Teixeira et al., 2013). These habitats may therefore sustain peculiar and dense macrofaunal communities similar to those found at cold seeps.

The Congo terminal lobe complex is divided into several lobes that were successively formed by channel input accumulation and successive bifurcation of the feeding channel (Babonneau et al., 2002; Dennielou et al., in press. this isssue; Savoye et al., 2009; Savoye et al., 2000). This prograding pattern has resulted in 5 lobes along the present-day active feeding channel with the oldest lobe (\#1) is the most proximal and the youngest (\#5) is the most distal (Fig. 1). They are now differentially affected by turbiditic currents and display high, but variable sedimentation rates with the highest in the youngest lobe while the abandoned lobes are still affected by channel spillover (Dennielou et al., in press. this isssue; Rabouille et al., in press this issue). Several sites were selected along the present-day feeding channel, from the entrance to the lobe system up to the main deposition area in 


\section{ACCEPTED MANUSCRIPT}

lobe \#5 $60 \mathrm{~km}$ away. Two more sites were studied north of the main axis, one in an abandoned lobe of the complex at $15 \mathrm{~km}$ north from the active channel and one related to an older, abandoned channel $45 \mathrm{~km}$ north(Fig. 1) (Rabouille et al., in press this issue).

In this study, we investigated how the exceptional great organic carbon input and highly dynamic environment of the Congo deep-sea fan affect the detritus- and chemosynthesis-based macrofaunal communities living in these deep-sea sediments. One objective was to compare the faunal response along spatial and temporal scales of turbiditic inputs. More precisely, we addressed the following questions: (1) Are macrofaunal densities enhanced by turbiditic inputs and does community diversity and composition differ from abyssal sediments? We have investigated macrofaunal communities from different sites along the present-day depositional area, as well as in an abandoned lobe about $50 \mathrm{~km}$ away and discussed their differences with respect to organic carbon contents and oxygen demand of the surface sediments; (2) Do the identified communities in chemosynthesis-based habitats differ from the background community and are they closely related to their cold-seep counterparts? What are the role of abiotic (chemical gradients) and biotic (vesicomyid engineer species) factors in structuring these communities? We analyzed diversity, composition and vertical distribution patterns of macrofauna sampled in various habitats (black patches of reduced sediment, microbial mats and vesicomyid clusters, adjacent sediment), together with chemical gradients and bivalve population variability between habitats; (3) Finally, by analyzing the spatial variability of macrofaunal community structure between chemosynthesis-based habitats, as well as its vertical distribution and geochemical gradients, we discuss a possible scenario of community succession.

\section{Materials and methods}

\section{Sampling sites and sediment characteristics}

A detailed description of the sampling strategy and sampling sites is given in Rabouille et al. (this issue). The samples were collected during two cruises, WACS (Olu, 2011) and Congolobe (Rabouille, 


\section{ACCEPTED MANUSCRIPT}

2011) which were conducted in February 2011 and December 2011-January 2012, respectively. They were collected either along the channel axis (sites A, F, and C) at $4765 \mathrm{~m}, 4875 \mathrm{~m}$ and $4950 \mathrm{~m}$ depth respectively, or north of the feeding channel (site B at $-4840 \mathrm{~m}, 10 \mathrm{~km}$ north and site $E$ at $-4765 \mathrm{~m}, 45$ km north)(Fig. 1). The sites in the active channel axis are affected by turbidity currents and supplied with present day material. The sites located along the present channel axis, are differently affected by 1) current intensity, which decreases from the entrance (site A) to the last depositional lobe (youngest lobe 5 , site $C$ ), and 2) sedimentation rates, which increase from the entrance (0.6 to 1 $\mathrm{cm} . \mathrm{yr}^{-1}$ ) up to the main depositional area (site $\mathrm{C}: 12-22 \mathrm{~cm} \mathrm{yr}^{-1}$ ). The other two sites correspond to lobes completely disconnected from the channel several thousands of years ago ( $E$ is located on the abandoned northern lobe complex) or within the last few thousand years ( $\mathrm{B}$ in lobe 3 ), still receiving channel material although much less than in the youngest lobe (sedimentation rate of 0.3 to $0.4 \mathrm{~cm}$ $\mathrm{yr}^{-1}$ ) (Rabouille et al., in press this issue).

The particulate organic material delivered by the Congo river is considered as quite homogeneously distributed (Stetten et al. 2015; Baudin et al. in press). Although a slight decrease in particle size was observed in levee sediments from site $A(11.3 \mu \mathrm{m})$ to site $C(6.6 \mu \mathrm{m})$ and site $E(7.2 \mu \mathrm{m})$, particle size did not significantly differ between sites; all sediments are very fine, dominated at $80 \%$ by fine siltyclay sediments, and a median grain size of $10 \mu \mathrm{m}$, because particle segregation occurs downstream the distal lobes, in the channel (Stetten et al., 2015).

The composition of the sediment does not vary significantly between sites, except for site $E$ (Baudin et al., in press a. this issue; Stetten et al., 2015): organic carbon content of the recent lobe complex was very high with a mean content per $\sim 20 \mathrm{~cm}$ long-multicores of $3.3 \%, 2.9 \%, 3.1 \%$ and; $3.7 \%$, respectively at sites $A, F, C$ and $B$ ) compared with the lower content at site $E$ (mean $1.6 \%$ but with a lower value of $0.7 \%$ in the top $7 \mathrm{~cm}$ of the core). C.O. contents of the first centimeter horizon were also quite homogeneous, from $2.85 \%$ on the levee at site $A$ to $3.7 \%$ from the levees and the depositional area at site C (Baudin et al., in press b. this issue). These values are one order of 


\section{ACCEPTED MANUSCRIPT}

magnitude higher than in Atlantic abyssal seafloor sediments (generally below $0.3 \%$, and rarely exceed 1\% (Mollenhauer et al., 2004).

Most of the organic carbon is of terrestrial origin based on estimations from isotopic carbon signatures (mean $\delta^{13} \mathrm{C}=-26.5 \%$ ) of between $70 \pm 3 \%$ (site B) and $79 \pm 3 \%$ (site $\mathrm{C}$ channel). Site $\mathrm{E}$, although receiving little turbiditic material shows a ${ }^{13} \mathrm{C}$ signature of the top $7 \mathrm{~cm}$ of sediments more similar to marine sediments: $-23 \%$ (Stetten et al. 2015).

\section{Sampling design}

Macrofauna were quantitatively sampled during ROV dives with a large blade corer $(20 \times 15 \mathrm{~cm})$ on decimeter-scale habitats, visually selected during ROV dives, and assumed to be based on chemoautotrophy (black patch of reduced sediment, microbial mats, vesicomyid clusters), or in their vicinity, in visually bare sediment. Macrofauna was sampled with USNEL box corers $(50 \times 50 \mathrm{~cm})$ on the channel levees considered to be a more homogeneous environment (Table 1; Fig.2). USNEL cores were sub-sampled by the same blade cores used by the ROV, to facilitate quantitative comparison, and ensure replicate (or triplicate) sampling for all sites.

The sampling sites and sampling design are fully described in Rabouille et al. (this issue). The sampling sites were usually physically marked during ROV dives (see Fig. 1 for marker locations). At Site A, a vesicomyid bed (Marker Col 2) was sampled along the gentle southern flank of the active channel in an area corresponding to an arcuate head wall interpreted as a slide scar (Dennielou et al., in press. this isssue). The area was called "Vesico Bay" as colonized by many vesicomyid patches (Sen et al., accepted, this issue). At site B, macrofauna were sampled in sediments sparsely colonized by vesicomyids (Marker CoL 11) located on the northern levee of a small sinuous channel. The chemosynthesis-based habitat sampled by ROV at site F was one of the several vesicomyid/microbial mat patches distributed around a small relief (Marker Col 3 ), located on the northwestern levee of 


\section{ACCEPTED MANUSCRIPT}

the channel showing flanks with scars and blocks. All chemosynthesis-based habitats sampled at site C were located in the widening channel in a relatively flat area (Markers Col 4, Col 8 and Col) respectively for microbial mats, black patch, and large vesicomyid bed. In chemosynthesis-based habitats or their vicinity, sampling was performed during ROV dives using blade corers (large blade cores) in triplicate: vesicomyid beds at sites A, B and C (respectively VesA, VesB, VesC), microbial mats at site $\mathrm{C}(\mathrm{MmC})$, mixed habitat (microbial mats and vesicomyids) at site $\mathrm{F}$ (MmVesF). Reduced sediment (a black sediment patch) was also sampled at site $C(\operatorname{RedC})$. Bare sediments adjacent $(<1$ m) to vesicomyid habitats at sites $A$ and $C$ were also sampled using blade corers ( $\operatorname{ddj} A, \operatorname{Adj} C$ ). Blade cores were also taken during a dive surveying the disconnected lobe at site $E$ where any chemosynthesis-based habitat was seen (Ref E). Finally, Usnel box cores were taken on the northern levees of the active channel, one at each site F and site C (Fig.1).

Tube cores were taken by the ROV within the chemosynthesis-based habitats, among vesicomyids and in microbial mats and reducing sediment, as well as in the adjacent bare sediment, to characterize chemical gradients (see Rabouille et al. in press, this issue, for detailed location of each sample). For the levees, similar cores were obtained using a multicorer. Autonomous benthic chambers were deployed either by ROV in the bare sediment adjacent to vesicomyid clusters or from the ship (lander) on the levees at sites C, F and B and at site E, to measure oxygen consumption (Fig. 1).

\section{Sample processing and sorting}

On board, blade cores were sliced in layers of various thickness. The top $5 \mathrm{~cm}$ were sliced in 3 layers $(0-1 \mathrm{~cm}, 1-3 \mathrm{~cm}, 3-5 \mathrm{~cm})$ except in cores containing vesicomyids. Below $5 \mathrm{~cm}$, the cores were sliced each $5 \mathrm{~cm}$ down to $15 \mathrm{~cm}$. Consequently, for the comparison between habitats, only three layers were considered $(0-5,5-10$ and 10-15 cm). Each slice was washed with filtered seawater and sieved on a column of $1 \mathrm{~mm}, 500 \mu \mathrm{m}, 300 \mu \mathrm{m}, 250 \mu \mathrm{m}$ mesh sizes. At each habitat, one sample was fixed in 


\section{ACCEPTED MANUSCRIPT}

$96 \%$ ethanol and the others were fixed in $4 \%$ buffer formalin for $48 \mathrm{~h}$ and transferred to $70 \%$ ethanol after 2 days.

In the laboratory, macrofauna sensus stricto (i.e. excluding meiofaunal taxa as described by (Dinet et al., 1985) were sorted at the class down to the family level and counted. Bivalves were identified by Elena Krylova as often as possible to the family level (a few specimens $>1 \mathrm{~mm}$ to species level). Nevertheless, the smallest individuals ( $250 \mu \mathrm{m}$ fraction and some of the $300 \mu \mathrm{m}$ fraction) were too small to be identified, even by the specialist, and were therefore counted as unidentified bivalves. Large $(>1 \mathrm{~cm})$ vesicomyids sampled in cores were not considered as part of the macrofaunal communities but were used to characterize the habitat. All adult vesicomyids sampled with different sampling tools manipulated by the ROV (cores, nets) were identified, measured and weighed.

Gastropods were identified at the species level by Anders Warén. In the lab, crustaceans were identified to the order level and polychaetes to the family level (supervision L. Menot).

\section{Chemical parameters}

Total hydrogen sulfide, sulfate and methane $\left(\Sigma \mathrm{H}_{2} \mathrm{~S}, \mathrm{SO}_{4}{ }^{2-}\right.$ and $\left.\mathrm{CH}_{4}\right)$ concentration profiles were obtained ex situ from the analysis of the pore water extracted from tube cores following the methodology described in (Pastor et al. subm.). The following parameters were retained for all three chemical compounds: concentration at the interface; concentration at $1 \mathrm{~cm}$ and at $5 \mathrm{~cm}$ below the surface; maximum concentration; depth of maximum concentration. Because no $\mathrm{H}_{2} \mathrm{~S}$ was measured at site $\mathrm{E}$, the depth of maximum $\mathrm{H}_{2} \mathrm{~S}$ concentration was not available at this site. $\mathrm{H}_{2} \mathrm{~S}$ diffusive fluxes were calculated from the pore water data of each sediment core using Fick's first law of diffusion $J=-\phi D s \frac{d C}{d z}$, where $\mathrm{J}$ is the flux, C is the concentration, $\phi$ the sediment porosity and Ds the molecular diffusion coefficient of $\mathrm{H}_{2} \mathrm{~S}$ within the sediment. Ds was calculated as $D s=\frac{D}{1+3(1-\varphi)}$ 


\section{ACCEPTED MANUSCRIPT}

(Boudreau, 1996), D is the molecular diffusion coefficient of $\mathrm{H}_{2} \mathrm{~S}\left(\mathrm{~cm}^{2} \mathrm{~s}^{-1}\right)$ at in situ temperature, salinity and hydrostatic pressure (Iversen and Jorgensen, 1985).

Oxygen penetration depth (OPD) values were obtained from micro-electrode profiles measured in situ or onboard from cores collected by the ROV or by the multicorer (Pozzato et al., subm. this issue).

Total oxygen demand was estimated using autonomous (RAP) and ROV-manipulated (Calmar) benthic chambers. The RAP respirometer (for a detailed description of this lander, see (Khripounoff et al., 2006) isolates and incubates a known volume of seawater in close contact with a sediment surface in three $30 \mathrm{~cm}$ diameter benthic chambers. Three sampling cells, positioned within the chambers, carry out water subsample collection $(100 \mathrm{ml})$ at predetermined intervals for later calculation of fluxes. Each chamber was also equipped with $\mathrm{O}_{2}$ optode probes (Aadi) that continuously recorded the $\mathrm{O}_{2}$ concentration in the chamber water. Incubation duration was between 24 and $48 \mathrm{~h}$. To assess the in situ gas exchange at a specific location, the Calmar benthic chamber was deployed by the ROV Victor. Calmar is a $41 \mathrm{~cm}$ diameter cylinder equipped with six $100 \mathrm{ml}$ sampling cells (identical to those used on the RAP respirometer), an oxygen probe (Aadi) and a stirrer to homogenize the water in the chamber (Caprais et al., 2010). The incubation lasted for about $6 \mathrm{~h}$ on the sediment. At each station, a ring of $50 \mathrm{~cm}$ in diameter was deployed to guide Calmar positioning (Khripounoff et al., 2015).

\section{Data analyses}

Mean macrofaunal densities and standard deviations were estimated for each habitat, and according to sediment depth. Diversity patterns across habitats were assessed using individual-based rarefaction curves (Gotelli and Colwell, 2001). The Hurlbert's diversity index computed on abundances of polychaete families (Hurlbert, 1971) was estimated for 50 individuals $\left(\mathrm{ES}_{50}\right)$ as the lowest number of individuals sampled in a given habitat was 57 individuals, at the Ref E site . Other diversity indexes (Shannon-Wiener diversity index $\mathrm{H}^{\prime}$ and equitability Pielou index $\mathrm{J}^{\prime}$ ) were also 


\section{ACCEPTED MANUSCRIPT}

estimated for each habitat. However, $\left(E_{n}\right)$ is the most suitable for non-standardised sample sizes (Soetaert and Heip, 1990).Variation in community composition across habitats and sites ( $\beta$-diversity) was analyzed using a principal component analysis (PCA). Abundance data were transformed to use the Hellinger distance among samples in the PCA instead of the Euclidean distance, as recommended by Legendre \& Gallagher (2001). The Hellinger distance gives lower weight to dominant taxa and does not consider double absence as an indicator of similarity between samples. A canonical redundancy analysis (RDA) was performed to test the influence of chemical factors on variation in the macrofaunal community structure between habitats and sites. Spearman correlations were performed between all chemical parameters to avoid co-linearity between them in the RDA. We kept as potentially explanatory variables those assumed to have the greatest ecological role (e.g. $\mathrm{H}_{2} \mathrm{~S}$ was preferentially chosen over $\mathrm{CH}_{4}$ level if correlated). Both PCA and RDA were performed using the ' $r d a$ ' function of the vegan R-language library and the R package (R Development Core Team, 2004). We also used a procedure to select the environmental variables of the RDA that contribute significantly to modeling the faunal densities at the different habitats (forward-sell procedure available in the vegan R-language library). Spearman rank correlations were performed between macrofaunal community density and Hurlbert' index $\mathrm{ES}_{50}$, environmental variables used for the PCA and vesicomyid density and mean size, to test the engineering effect of these habitat-forming species. This analysis was carried on chemosynthesis-based habitats, with or without adjacent sediment samples.

\section{Results}

\section{Density}

Macrofauna mean density was highly variable between habitats (Table 2; Fig. 3; Table S1), varying by two orders of magnitude between the lowest at the reference site E (RefE, 1001 ind. $\mathrm{m}^{-2}$ ) and the 


\section{ACCEPTED MANUSCRIPT}

highest in the black reduced sediment (RedC, 65,699 ind. $\mathrm{m}^{-2}$ ). Density was also very high in microbial mats (MmC) 42,525 ind. $\mathrm{m}^{-2}$ at site $\mathrm{C}$, and intermediate in the mixed habitat microbial mats/vesicomyids at site $\mathrm{F}\left(\mathrm{MmVesF}, 18036\right.$ ind. $\left.\mathrm{m}^{-2}\right)$. Densities were relatively homogeneous in vesicomyid habitats and adjacent sediments (from 3795 ind. $\mathrm{m}^{-2}$ at VesA to 8713 ind. $\mathrm{m}^{-2}$ at VesC), and fell in the range of densities found in the levee sediments (6766 at LevF to 7756 ind. $\mathrm{m}^{-2}$ at LevC).

The vertical distribution of macrofauna densities was averaged by habitat (Fig. 4a). The macrofauna were always more abundant in the first $5 \mathrm{~cm}$, with the exception of the LevC. The reference site (RefE), the reduced sediment (RedC), and the microbial mat habitats ( $\mathrm{MmC}$ and MmVesF) showed more than $95 \%$ of the fauna within the first $5 \mathrm{~cm}$. Vesicomyid habitats at site $B$ also had a high proportion with 92\%, whereas the proportions in the vesicomyid habitats at sites A and C (VesA and VesC) were lower with $72 \%$. Densities were variable in the sediment adjacent to vesicomyid beds (AdjA and AdjC, 50 to 76\%), and the fauna were more evenly distributed (at least to $10 \mathrm{~cm}$ depth) in the levees at sites C (LevC, 36\% in the first $5 \mathrm{~cm} ; 54 \%$ in the $5-10 \mathrm{~cm}$ ) and $\mathrm{F}$ (LevF, $54 \%$ in the $0-5$ slice).

Polychaete vertical distribution followed the general macrofaunal pattern with most of the individuals in the shallowest $5 \mathrm{~cm}$ of sediment. However some families such as the Cossuridae were found in higher proportions below $5 \mathrm{~cm}$ depth, and were still abundant at $15 \mathrm{~cm}$ depth (Fig. 4b). Other mobile polychaetes were found in these layers, such as spionids or dorvilleids, capitellids and hesionids. However, some families, such as ampharetids living in tubes, should not be found below 5 $\mathrm{cm}$ depth, although occasionally sampled until $10 \mathrm{~cm}$ depth (Thurber et al. 2013). Ampharetid occurrence in deeper sediment layers may be an artefact due to individuals sliding along the core edges during the slicing process.

\section{$\alpha$-Diversity}




\section{ACCEPTED MANUSCRIPT}

Taxonomic richness varied between 7 and 20 taxa, including 3 to 15 polychaete families. The lowest richness was observed in the sediment AdjA adjacent to VesA (but only one blade core) and the highest at RefE, despite a low number of sampled individuals (91 ind.) (Table 2). Among chemosynthesis-based habitats, the number of polychaete families was lower in microbial mats, reduced sediments and in the mixed habitat MmVesF (5 to 7), compared with all vesicomyid beds (10 to 11). Number of polychaete families was as low in the levee cores (LevC and LevF, 6 families) as in the least diverse chemosynthesis habitats (i.e. RedC, MmVesF).

Rarefaction curves showed that some habitats were sufficiently sampled to assess polychaete diversity (Fig. 5): those showing the lowest richness (MmC, RedC, MmVesF) and intermediate richness (VesC, LevC). The AdjA curve also reached a plateau, but only one core was sampled in this habitat, precluding any conclusions. Other habitats were largely under-sampled (RefE, VesB, AdjC, LevF) and cannot be ranked with confidence, but high diversity is clearly expected at RefE and VesB. For vesicomyid beds, an increasing trend was observed from VesC to VesA to VesB.

Habitats with the lowest expected richness were also dominated by a low number of families: Hesionidae polychaetes represented $74 \%$ and $49 \%$ of the total macrofauna in microbial mats at site $\mathrm{F}$ (MmVesF) and C ( $\mathrm{MmC})$, respectively, whereas Dorvilleidae dominated the reduced sediment at site C (RedC), accounting for $63 \%$ of the macrofauna. These habitats were characterized by low eveness $\left(J^{\prime}\right)$ and expected richness based on polychaete families $\mathrm{ES}_{50}$ (Table 2). In the levee, dominant taxa also accounted for a large part of the density; Cossuridae represented $66 \%$ of the total macrofauna in LevF, and Tanaidacea $47 \%$ at LevC.

\section{Community composition and $\beta$ - diversity}

Macrofauna was dominated by polychaetes (64 to $94 \%$ of total macrofauna) at most sites and habitats. However, tanaids co-dominated with cossurids in sediments adjacent to vesicomyids (AdjC), and on the levee at site $C(\operatorname{LevC})$, and isopods co-dominated with tanaids and cossurids at site B (VesB). One noticeable exception was the reducing sediment sampled at site C (RedC), where 


\section{ACCEPTED MANUSCRIPT}

hyalogirinid gastropods represented almost half of the macrofauna with more than 40,000 individuals.m ${ }^{-2}$. All the specimens likely belong to the same species, closely related to Hyalogyrina rissoella Warén \& Bouchet (2009), described from cold seeps on pockmarks. This family was also abundant in microbial mats of the same site $(\mathrm{MmC})$, but in lower densities and with large heterogeneity between replicate cores.

The PCA separated habitats well and showed that replicate cores within habitats were relatively similar (Fig. 6). The first axis (43\% of the variance) isolates all chemosynthesis-based habitats of site C, together with the microbial mat/vesicomyid habitat of site F, dominated by hesionids, dorvilleids or hyalogirinids, from site B vesicomyids, all adjacent sediments, all levee sediments, and the reference site E dominated by cossurids, tanaids and isopods. Site A (with one core from AdjC) is located between the two groups. The second PCA axis (18\% of the variance) separates site A vesicomyid beds(VesA), with significant contribution of spionids, from reference site $E$. The third PCA axis (12\%; not shown) also separates reference site $E$ from the other sites. The different habitats sampled at site C are separated by the second and third PCA axes, with a gradient from RedC, dominated by dorvilleids and hyalogirinids, to $\mathrm{MmC}$ and then VesC dominated by hesionids and ampharetids. Microbial mats have an intermediate composition between vesicomyid beds and reduced sediments at site $\mathrm{C}$, with dominance of hesionids, but also dorvilleids and hyalogirinids. Vesicomyid juveniles were abundant in the microbial mats at site $C\left(\sim 7000\right.$ ind. $\left.\mathrm{m}^{-2}\right)$, although not visible in the PCA due to the dominant taxa with even higher densities and also due to high variability between cores (Table 2, Table S1). The mixed habitat sampled at site $\mathrm{F}$ with microbial mats and vesicomyids (MmVesF), showed patterns intermediate to the microbial mat (sharing dominance of hesionids) and the vesicomyid beds sampled at site $\mathrm{C}$ and $\mathrm{A}$ (spionids).

\section{Chemical factors contributing to macrofaunal community structure}

\section{Analysis on all samples}




\section{ACCEPTED MANUSCRIPT}

The first RDA was performed on all sites and all sampled habitats. Positive correlations were found between sulfide and methane concentrations at the interface, $1 \mathrm{~cm}$ and $5 \mathrm{~cm}$ below the seafloor (bsf) (all $\mathrm{p}<0.005$ ). Negative correlations were found between sulfate and methane concentration at $5 \mathrm{~cm}$ bsf, minimum sulfate and maximum methane concentration $(p=0.005)$. Finally, the depth of minimum sulfate was correlated with the depth of the highest methane concentration $(p=0.01)$. The values of methane concentrations should be considered as conservative estimates due to a possible bias in measurement due to decompression that probably occurred during sample retrieval. Therefore, when correlated with methane, $\mathrm{H}_{2} \mathrm{~S}$ and $\mathrm{SO}_{4}{ }^{2-}$ values were used preferentially. Moreover, because sulfide is assumed to be more constraining for macrofauna than sulfate due to its toxicity, $\mathrm{H}_{2} \mathrm{~S}$ was used rather $\mathrm{SO}_{4}{ }^{2-}$ when these two factors were correlated. The following variables were therefore used for the analysis: the concentrations of hydrogen sulfide at $1 \mathrm{~cm}$ bsf $\left(\mathrm{H}_{2} \mathrm{~S}-1 \mathrm{~cm}\right)$ and maximum concentration within the core $\left(\mathrm{H}_{2} \mathrm{~S} \_\right.$max $)$, the sulfide diffusive flux $\left(\mathrm{H}_{2} \mathrm{~S} \_\right.$flux $)$, the minimal concentration of sulfate $\left(\mathrm{SO}_{4}{ }^{2-}-\mathrm{min}\right)$ and its depth of occurrence $\left(\mathrm{SO}_{4}{ }^{2-}\right.$-mindep), and the oxygen penetration depth (OPD).

The resulting redundancy analysis is shown in Figure 7A. The RDA was significant (ancova, $p=0.005$ ). Among the chemical factors tested, $\mathrm{SO}_{4}{ }^{2-}$ min and OPD contributed significantly (respectively $\mathrm{p}=0.003$ and $p=0.02$ ) to the RDA, according to the selection procedure (forward.sel). With these two explanatory variables, the RDA was significant with almost $60 \%$ of the variation explained by the two first axes ( $43.6 \%$ and $16 \%$ respectively). The minimal sulfate concentration $\left(\mathrm{SO}_{4}{ }^{2-} \mathrm{min}\right)$ contributed to the first RDA axis, which separates the levee, reference station, adjacent sediments and vesicomyid habitat at site B from all other chemosynthesis-based habitats at sites $C$ and $F$. OPD isolates the reference site along the second RDA axis. Among other factors, the sulfide flux, which showed the highest values at the reduced sediment habitat, was correlated with the dominance of hyalogirinid gastropods and dorvilleids, whereas the levels of sulfide at $1 \mathrm{~cm}$ below the surface and its maximum level were correlated with the presence of hesionids at the vesicomyid habitat at site $C(V e s C)$ and the mixed microbial/vesicomyid habitat at site $\mathrm{F}(\mathrm{MmVesF})$. Habitats isolated along the negative part 


\section{ACCEPTED MANUSCRIPT}

of the first RDA axis were also characterized by a deeper sulfate minimum than the other habitats. This sulfate consumption should result in sulfide production, whose depth should influence macrofauna composition in the first $10 \mathrm{~cm}$ of sediment.

\section{Chemosynthesis-based habitats and adjacent sediments}

A RDA was run on seven sites, including chemosynthesis-based habitats and adjacent sediments (Fig. 7B). Compared with the first RDA, the depth at which the maximum sulfide concentration was measured ( $\mathrm{H}_{2} \mathrm{~S}$ _maxdep) was added as an explanatory variable. $\mathrm{SO}_{4}$ mindep, which was positively correlated with $\mathrm{H}_{2} \mathrm{~S} \_$maxdep $\left(r^{2}=0.67 ; p=0.01\right)$, was removed.

The minimal concentration of sulfate (here indicative of the total sulfate consumed within the sampled sediment) again explained most of the variation, contributing to the isolation of vesicomyids of site B and adjacent sediments from chemosynthesis habitats of sites C and F. The depth of minimum sulfide also contributed to the separation of these two groups, as well as the oxygen penetration depth (OPD) and the depth of maximum sulfide, which both tended to be correlated with the dominance of tanaids and isopods at VesB and AdjA. Hyalogirinids were linked to the highest sulfide flux, dorvilleids to sulfide flux and maximum sulfide concentration, whereas hesionids were correlated with higher sulfide levels close to the surface. The dominance of spionids at the VesA station was not strongly associated with the chemical variables tested.

Spearman rank correlations performed between environmental variables and macrofaunal density and diversity $\left(\mathrm{ES}_{50}\right)$ in chemosynthesis-based habitats and adjacent sediments show a negative correlation between minimum sulfate concentration and macrofaunal density $(\rho=-0.78 ; p=0.02$; or $\rho=-0.94, p<0.005$ without considering adjacent sediments). No correlation was found between macrofaunal density or diversity and sulfide concentrations at $1 \mathrm{~cm}$, or maximum sulfide flux and maximum sulfide depth. 


\section{ACCEPTED MANUSCRIPT}

\section{Vesicomyid population characteristics}

Vesicomyid population characteristics at each site are given in Table 4. The highest densities were recorded at site $\mathrm{C}$ (VesC) where the bivalves were densely packed (Fig. 2h). Vesicomyid densities were also high at site A (VesA). At both sites, densities estimated from images and those counted in macrofauna cores (large blade cores) were in the same range. Densities were much lower at sites $\mathrm{F}$ and $\mathrm{B}(\mathrm{MmVesF}$ and VesB) where no bivalves were sampled in the blade cores even though the cores were taken among the sparsely distributed vesicomyids. Vesicomyids shared the habitat with microbial mats at site F; empty shells were also present at site B.

Two species of vesicomyids co-occurred, but their proportions varied among sites. Sites $A$ and $C$ were highly dominated by Christineconcha regab which accounted for more than $90 \%$. Abyssogena southwardae was more abundant in site F (40\%) and dominated largely at site B (87\%). Except at site $C$ where this species was rare, $A$. southwardae had longer shells than $C$. regab, its shell length being longer than $100 \mathrm{~mm}$ at the three other sites, whereas C. regab varied between 60 and $73 \mathrm{~mm}$ (Table 4). Considering both species together, there were also size differences between the sites, with increasing size from site $\mathrm{C}$ to $\mathrm{A}$ and $\mathrm{F}$ partially due to the presence of $A$. southwardae, but also because $C$. regab size increased from $C$ to $A$.

A positive Spearman rank correlation was found between macrofaunal diversity $\left(E_{50}\right)$ and vesicomyid density in chemosynthesis-based habitats, either considering mean vesicomyid density in cores $(\rho=0.84, p<0.05)$ or mean density per habitat using both images and cores $(\rho=0.89, p<0.05)$. This correlation was also significant if adjacent sediment samples were included. However, macrofauna density was negatively correlated with vesicomyid density $(\rho=-0.81, p<0.05))$.

\section{Respiration measurements}

Total oxygen uptake (TOU) estimated from the in situ measurements taken with the RAP respirometer and Calmar benthic chamber varied between 5.4 and $9.6 \mathrm{mmol} . \mathrm{m}^{-2} . \mathrm{d}^{-1}$ (Table 5). There 


\section{ACCEPTED MANUSCRIPT}

was an east-west gradient for the oxygen uptake rate from site $A$ to $C$, but TOU values were relatively homogeneous, except in the adjacent sediment of the vesicomyid bed at site C (AdjC), slightly higher than in adjacent sediment at site $\mathrm{A}(\mathrm{Adj} A)$ and on the levees (LevC and LevF). In strong contrast to the active lobe area, reference site $E$ showed a much lower TOU rate $\left(1.1 \mathrm{mmol} \cdot \mathrm{m}^{-2} \cdot \mathrm{d}^{-1}\right)$. Macrofaunal densities in bare sediments (both adjacent to vesicomyid beds and on the levees) were positively correlated with TOU but the Spearman correlation was not significant $(\rho=0.82, p=0.09)$.

\section{Discussion}

Direct use of turbiditic inputs: enhanced macrofaunal densities and unusual community composition

The unique characteristics at abyssal depths of the Congo deep-sea fan sediments give the opportunity to study the deep-sea faunal response to such an organic-enriched but dynamic environment. The low macrofaunal densities found in the sediment of the channel levees at $4000 \mathrm{~m}$ depth, raised the question of the nutritional quality of the turbiditic material (Galéron et al., 2009). However, the present study focusing on the lobe area, shows a different macrofaunal response.

Macrofaunal densities in sediments in the active lobe area (sites A, F, C) were relatively homogeneous either in bare sediment adjacent to vesicomyid beds or in the levees. This uniformity is reflected in the organic carbon content of sediments, which showed limited variation between these sites, suggesting that particulate organic carbon delivered by the Congo River is homogeneously distributed (Stetten et al., 2015). These densities were much higher (with a factor of 7 to 8) than in the sediments sampled at reference site $\mathrm{E}$, located in an abandoned lobe complex $45 \mathrm{~km}$ north of the presently active channel. Organic carbon content at this site (1.6\%) was much lower than in the active lobe area (3.3 to 3.9\%) (Stetten et al., 2015). The origin of particulate organic material also differed between areas, with a larger contribution of terrestrial material in the active lobe area than 


\section{ACCEPTED MANUSCRIPT}

in the old lobe complex characterized as a transition between fully marine and turbiditic deposit

(Stetten et al., 2015). Therefore, macrofaunal communities colonizing sediments at $5000 \mathrm{~m}$ depth fully benefit from the predominately terrestrial organic matter inputs. In parallel, biogeochemical characterization of the sedimented organic matter suggested that despite being mostly composed of soil-derived organic matter considered as poorly digestible, these turbiditic deposits are sufficiently labile (e.g. high proteaginous nitrogen content) to support dense benthic communities (Pruski et al., accepted, this issue). These results contrast with the low meiofaunal densities (Van Gaever et al., 2009a) found in the $45 \mathrm{~m}$ deep-channel channel bed at the entrance of the lobe system (site A), likely affected by strong currents, and characterized by more sandy deposits than on the levees (Dennielou et al. this issue) . Physical conditions likely differ in the $1400 \mathrm{~m}$ wide and $11 \mathrm{~m}$ deep "channel" at site C, that is more a spreading area rather than a channel (Rabouille et al., in press this issue) where the energy flow is likely distributed and sediment dominated by muddy deposits (Dennielou et al., in press. this isssue), allowing higher faunal densities. The sedimentation rates which also vary along the system, from site A levees (0.6 to $\left.1 \mathrm{~cm} \cdot \mathrm{yr}^{-1}\right)$ to site $C\left(12-20 \mathrm{~cm} \cdot \mathrm{yr}^{-1}\right)$ (Rabouille et al. in press) do not seem to affect macrofauna densities.

Variability in macrofaunal density patterns in bare sediments (levees and sediment adjacent to vesicomyid beds) was consistent with those of oxygen uptake. TOU values showed low variability among sites, supporting the homogeneous pattern found in macrofaunal densities in the active lobe sediments, and the striking contrast with those of the disconnected lobe. The TOU in the active lobe area was 3 to 4 times higher in magnitude than TOUs measured at similar depths with values of between 1.5 to $3 \mathrm{mmol} \cdot \mathrm{m}^{-2} \cdot \mathrm{d}^{-1}$ (Wenzhöfer and Glud, 2002); for review). This large difference is consistent with an increase in faunal densities in the lobe area. TOUs measured along the Congo margin around $4000 \mathrm{~m}$ depth by the same device used in the lobe area, were lower by a factor of 3 or 4 than those measured in the active lobe complex, both on the channel levee and $150 \mathrm{~km}$ southward (between 1.9 and 2.4 mmol. $\mathrm{m}^{-2} \mathrm{~d}^{-1}$ ) (Rabouille et al., 2009). 


\section{ACCEPTED MANUSCRIPT}

Similarly, macrofaunal densities in the Congo margin sediments and in the channel levees between 3000 and 4000 m depth (1304 to 3900 ind. $\mathrm{m}^{-2}$ ) (Galéron et al., 2009) are much lower, by a factor of 2 to 5 , than those estimated in the active lobe area. Organic carbon contents (1.2 and $2.5 \%)$ are also all lower than in the active lobe area. This difference may be related to low spillover between the channel and the levees before the lobe entrance or to high-frequency physical disturbance. However, macrofaunal densities of the Congo margin are among the highest reported at similar depths (Galéron et al., 2009). In comparison, a density of only 231.5 ind. $\mathrm{m}^{-2}$ is estimated at $4700 \mathrm{~m}$ in the tropical north-east Atlantic (Cosson et al., 1997). Although it was not possible to compare densities of the Angola basin due to different sieving mesh size, the total organic carbon content of these sediments of $0.6 \%$ (Kröncke and Türkay, 2003) is much lower than in the Congo lobes - even at the least enriched site E - further suggesting that the high macrofaunal densities in the Congo lobes stem from the terrigenous inputs. Although total organic carbon concentration is an ambiguous parameter for predicting macrofaunal densities due to its refractory character in deep-sea sediment (e.g. (Rowe et al., 1990)), the labile nature of the organic matter in the sediments of the Congo lobes (Pruski et al., accepted, this issue) supports the hypothesis of higher endobenthic densities correlated with the organic carbon content.

Another striking feature is the dominance in the lobe sediments of an unusual macrofauna composition. As observed for density, community structure was quite homogeneous in the active lobe area without any strong differences between the levees and the adjacent sediment to vesicomyid beds along canyons flanks or in the flat deposition area at site $\mathrm{C}$. Cossurid polychaetes and tanaids dominated at all stations. Other abundant taxa, although more heterogeneously distributed, were spionid polychaetes and isopods. This composition differed from sediments sampled upstream from the lobes, in the channel levee where paraonid and pilargid polychaetes dominate around 4000 m (Galéron et al., 2009). A typical deep-sea community was also found between the channel and the Regab pockmark around $3000 \mathrm{~m}$ depth with dominance of spionids, paraonids and cirratulids (Menot et al., 2010). Cossurids were almost absent in these channel-levee 


\section{ACCEPTED MANUSCRIPT}

sediments, but abundant in cold-seep sediments of the nearby pockmark, together with other sulfide-tolerant polychaete families (capitellids, ampharetids or dorvilleids). Cossurids have been reported from other cold-seep sites, especially in vesicomyid or mytilid bivalve assemblages (Levin et al., 2003; Menot et al., 2010). Found deeper than other polychaete families, at the sulfide-oxygen interface (Levin et al., 2010), these sub-surface deposit feeders are assumed to be more tolerant to sulfide and to possibly feed on the microbial biomass. Their dominance in the lobe sediments may be related to the presence of sulfide that was observed at each of the sites, except at the reference site E. Although sulfide levels outside of chemosynthesis-based habitats were in low concentrations (2-30 $\mu$ mol..$^{-1}$ ) and generally found quite deep (between 6 and $20 \mathrm{~cm}$ depth), oxygen penetration depth in the whole active lobe area was much lower than in the older lobe at site $E(1.5$ to $2.5 \mathrm{~cm} v 5 \mathrm{~cm})$. Cossurids are able to live deep inside the sediment by their ability to burrow themselves owing to their muscular anterior anatomy (Jumars et al. 2015 for review) and to be tolerant to hypoxia: their dominance in sediments in the oxygen minimum zone has been attributed to their morphological adaptation with expanded branchial structures (Levin et al., 2010). This ability to burrow may allow them to benefit from microbial production at depths, but also to avoid sediment surface disturbance by turbiditic flows and high sedimentation rates. This adaptation may provide a competitive advantage over other polychaete families in the highly dynamic environment of the lobe area. They may also compete better than polychaetes typically found in the deep sea for the massive arrivals of organic matter, leading to anoxia/sulfide production.

The massive inputs of predominantly terrestrial organic matter in the terminal part of the Congo deep sea fan therefore sustains outstanding macrofauna densities for this depth, likely related to the high organic content of the sediments. Contrasting with the upstream channel levee and the channel bed in the entrance of the lobe system, infauna can adapt to the exceptional sedimentation rates and disturbance by turbiditic currents. This may explain the unusual composition of the macrofaunal communities more closely related to low-flow cold-seep habitats or oxygen minimum zones than to typical deep-sea sediments. 


\section{Cold-seep-like communities sustained by turbiditic inputs: abiotic and biotic structuring factors}

Although high organic carbon content was pervasive in the active lobe area, chemosynthesis-based habitats have a patchy distribution (Sen et al., accepted, this issue). It is difficult to link chemosynthesis-habitat occurrence with organic carbon content because, although the very high values in microbial mats and black sediments at site $\mathrm{C}$ ( 4.8 and $5.2 \%$ respectively) can be due to the exceptional in faunal densities, carbon contents do not differ from adjacent and levee sediments in vesicomyids clusters with an average value of 3.6\% (Baudin et al., in press a. this issue). Conversely, chemosynthesis-based habitats seem to be controlled by the lobe morphology and small scale discontinuities. Chemosynthetic organisms colonize the channel flank and the levees, but not the 45m deep channel at sites $A$ and F, while they form dense colonies in the deposition area at site $C$, where the channel widens and becomes rather flat (Rabouille et al., in press). Vesicomyid bivalve beds and microbial mats were assumed to be favored by sediment instabilities leading to sulfide layer exhumation, but limited by turbiditic currents in the channel due to their erosive action and physical disturbance of the upper sediment layers (Sen et al., accepted, this issue). Early diagenesis of the high amounts of organic matter mainly occurs anaerobically through sulfate reduction and anaerobic methane oxidation (Pastor et al., accepted, this issue). These processes produce enough sulfide to sustain chemosynthesis-based primary production and the development of biogenic habitats that resemble those colonizing typical cold seeps on pockmarks.

Chemosynthesis-based habitats of the active lobe area, including microbial mats and vesicomyid beds, looked very similar to those observed on the Regab pockmark. They were generally observed in association with black reduced sediment, but many black patches are not colonized by vesicomyids (Sen et al., accepted, this issue). The macrofaunal community of these chemosynthetic habitats showed densities as high as their cold-seep counterparts. The highest densities found in the Congo lobe reduced sediments and microbial mats reach the highest recorded densities at cold seeps in 


\section{ACCEPTED MANUSCRIPT}

siboglinid tubeworm fields (Decker et al., 2012b), ampharetid beds (Thurber et al., 2013), or microbial mats (Guillon et al., 2017). These high densities of symbiont-bearing species and heterotrophic macrofauna are supported by methane fluxes in the range of those measured at cold seeps (Boetius and Wenzhöfer, 2013; Decker et al., 2012a; Khripounoff et al., 2015). Macrofaunal density was inversely correlated to minimum sulfate concentrations, assumed to reflect the quantity of sulfate consumed to produce hydrogen sulfide. Macrofaunal density was therefore positively linked to $\mathrm{H}_{2} \mathrm{~S}$ production.

\section{Variability along chemical gradients}

Macrofauna community composition in soft-sediment cold-seep habitats is known to be controlled by both methane and sulfide concentrations and fluxes (Decker et al., 2012b; Levin et al., 2003; Portail et al., 2015; Ritt et al., 2011; Sahling et al., 2002). Microbial mats are generally the most sulfidic habitats, with high sulfide concentrations, fluxes and production in the upper centimeters of the sediment. Sulfide concentrations in the microbial mats sampled in our study were one or two orders of magnitude lower than those reported for microbial mats at cold seeps whose maxima vary between 4 to 26 mM (de Beer et al., 2006; Levin et al., 2003; Sahling et al., 2002), but in the lower range of those measured in microbial mats of the Regab pockmark (Pop Ristova et al., 2012). In this pockmark, like in the lobe zone, microbial mats are not particularly large or thick, in contrast to those of the Haakon Mosby Mud volcano for example (Niemann et al., 2006). Although very high sulfide concentrations ( $>20 \mathrm{mM}$ ) have been measured in other mats of the lobe area, concentrations were still low in the first $5 \mathrm{~cm}$ (Pastor et al., accepted, this issue). These "medium" sulfidic conditions likely explain the high macrofaunal densities found in the mats at MmC. This chemical setting contrasts with other cold seep microbial mats where high fluid flows (or methane concentration) are assumed to limit macrofauna densities (Portail et al., 2015; Decker et al. 2012b). However, the macrofaunal community in microbial mats of the lobe area showed diversity and composition patterns generally encountered in cold-seep microbial mats, with low diversity at the family level and dominance of 


\section{ACCEPTED MANUSCRIPT}

sulfide-tolerant or specialized taxa: hyalogirinid gastropods, dorvilleid and hesionid polychaetes (Levin, 2005; Levin et al., 2013; Levin et al., 2003; Menot et al., 2010; Portail et al., 2015; Sasaki et al., 2010; Thurber et al., 2013). The macrofauna in the black reduced sediment of site $C$ was dominated by the same three taxa as in microbial mats, although not in the same order of dominance. In the reduced sediment, the relatively high densities of hyalogirinid gastropods - which are assumed to feed on microbial mats (Warén and Bouchet, 2009) - may also explain the absence of these mats at the surface of reduced sediments. In contrast, lower gastropod densities in the mats allow better mat growth, and highly sulfide-tolerant polychaetes (dorvilleids, hesionids) become more competitive. According to the redundancy analysis, the sulfide flux - which is highest in this habitat - drives this pattern. Again, the relative low sulfide flux and the low sulfide concentrations measured at the $\mathrm{MmC}$ site are not consistent with its faunistic composition, possibly indicating that the mat is in transition. One hypothesis is that (1) the sulfide flux has ceased in this mat, and (2) the sulfide has been consumed by the mats (assumed to be formed by sulfur-oxidizing, filamentous bacteria), but the community composition has not shifted toward a less sulfidic stage yet. The occurrence of vesicomyid juveniles, able to colonize the mat with low sulfide levels (and therefore limited hypoxia) close to the sediment-water interface, may be the first step for the shift toward a new community and a new habitat, the vesicomyid bed (see below).

\section{Beta-diversity driven by vesicomyid plasticity}

The vesicomyid beds sampled in the lobe area were similar to cold-seep beds, in terms of vesicomyid densities (Decker et al., in press this issue; Guillon et al., 2017; Olu-Le Roy et al., 2007; Sahling et al., 2002), sulfide levels and fluxes (Pop Ristova et al., 2012; Sahling et al., 2002) and macrofaunal densities (Guillon et al., 2017; Menot et al., 2010; Portail et al., 2015).. The two vesicomyid species, Christineconcha regab and Abyssogena southwardae sampled in the lobe area also colonize pockmarks of the Congo margin (Decker et al., in press this issue; Teixeira et al., 2013): the dominant species $C$. regab is also dominant on the Regab pockmark, whereas A. southwardae sampled in the 


\section{ACCEPTED MANUSCRIPT}

Worm Hole pockmark (Sahling et al., 2008; Teixeira et al., 2013) is a amphi-Atlantic species in cold seeps or hydrothermal vent sedimentary areas (Krylova et al., 2010). The macrofaunal community of the vesicomyid habitat in the active lobe area is heterogeneous and may be driven by the variability in geochemical gradients. The vesicomyid cluster at site $\mathrm{C}$ is dominated by hesionids which also dominate in microbial mats. Ampharetids are also abundant among vesicomyids at $\mathrm{Ves} C$, as observed in vesicomyid clusters of the active center of the Regab pockmark (Guillon et al., 2017). Spionids dominant at site VesA are associated in the Regab pockmark with the highest methane and sulfide fluxes in mytilid beds (Guillon et al., 2017; Pop Ristova et al., 2012). Spionids are also reported from reduced sediments assumed to be highly sulfidic, in the Nile delta (Ritt et al., 2011). Their dominance at VesA may be therefore related to the relatively high sulfide concentrations close to the surface and the lowest oxygen penetration of all sampling sites. The sulfide flux at VesA was also the highest among vesicomyid clusters. Finally, cossurids were able to colonize vesicomyid clusters at site A, likely owing to their resistance to hypoxia (Levin et al., 2010). Their ability to burrow may also help cossurids reach deeper sulfide layers and the associated microbial communities, and explain their dominance at VesB where the sulfide peak is deeper. In the Regab pockmark also, cossurids colonize vesicomyid beds (Menot et al., 2010), but particularly those where sulfide production via AOM is the deepest, associated with the lowest methane fluxes (Guillon et al., 2017).

The dominance of one polychaete family at one site may also be related to their adaptation to feed on, or to better compete for, one particular microbial population, or to feed on an abundant eukaryote prey. Hesionid frequentely predate harpacticoid copepods (Jumars et al. 2015) that may be abundant at seeps (Van Gaever et al., 2009b) but may also rely on mat forming filamentous bacteria or other microbial populations (reviewed by Jumars et al. 2015). The deposit-feeding ampharetids in New Zealand seeps primarily consume aerobic methanotrophic bacteria (Thurber et al., 2013). The high diversity of aerobic methanotrophs found in the vesicomyid sediments of the lobe complex (Bessette et al., in prep) may favor the settlement of ampharetids in this habitat. Dorvilleids are able to feed on AOM aggregates including both methanotrophic archaea and sulfate- 


\section{ACCEPTED MANUSCRIPT}

reducing bacteria but also on sulfide-oxidizing bacteria or methanotrophic bacteria in the upper aerobic layers of sediment (Levin et al., 2013; Thurber et al., 2012); the isotopic signature and fatty acid content of lobe specimens sampled in vesicomyid beds suggest that they rely on sulfatereducing bacteria and anaerobic methanotrophic archaea (ANME) (Pruski et al., accepted, this issue), but as resource partitioning may occur between taxa and even within the same species of dorvilleids (Levin et al., 2013), individuals from different habitats or within the same habitat by vertical partitioning may differ in their trophic niche. Different polychaete families also share the same habitat, each specialized on a particular trophic niche, according to their mobility, sulfide and hypoxia tolerance, and feeding preference or specialization on a particular microbial community. Trophic diversity and specialization of heterotrophic fauna has been suggested to be higher in low-flow habitats, such as vesicomyid beds, compared to high-flow ones (e.g. microbial mats) (Portail et al., 2016).

The high beta-diversity of polychaete families among vesicomyid beds sampled in the lobe area seems to be partially explained by geochemical gradients resulting from sulfide production and fluxes. However, sulfide fluxes and concentrations measured in the sediment do not completely reflect sulfide production because part of this sulfide is consumed, either by free-living or symbiotic sulfide-oxidizers or by inorganic precipitation with reduced iron or oxidation with iron hydroxides (Taillefert et al., subm. this issue). Sulfide production rates obtained by modeling the sulfate profiles showed sulfide loss in vesicomyid beds, mainly attributed to vesicomyid sulfide consumption (estimated from gill incubations) (Pastor et al., subm. this issue). This process is likely enhanced in the densest vesicomyid beds and therefore higher at site $C$ where vesicomyid density was almost twice than at site $A$ (and much higher than at $F$, and $B$ ). The vesicomyid themselves therefore shape geochemical gradients and, according to their density or behavior, create a heterogeneous habitat for macrofauna.

In addition to differences in sulfide fluxes and concentrations, the depth of maximum sulfide (depth of the peak in sulfide concentrations) appeared to be the most variable factor among vesicomyid 


\section{ACCEPTED MANUSCRIPT}

beds and to contribute to macrofaunal structure differences between site $\mathrm{B}$ and the other sites. The macrofaunal composition at this site was more closely related to the background sediment (dominance of isopods and cossurids) than to vesicomyid beds sampled in the active lobe area. Except at site $\mathrm{F}$ where microbial mats and vesicomyid beds co-occur, the depth of the maximum sulfide concentration under vesicomyid beds was correlated with vesicomyid size. Maximum sulfide concentrations were found at increasing depth $(7,9$ and $17 \mathrm{~cm})$ respectively at site $C, A$ and $B$, whereas average vesicomyid length varied from 59.1, 77.1 to $114.8 \mathrm{~mm}$, respectively. Vesicomyids have been shown to enhance sulfate penetration and deepen the sulfide production zone by bioirrigation (Fischer et al. 2012). In our study, the thickness of the sediment layer affected by this process was related to vesicomyid size, with longer vesicomyids in areas where the sulfide layer occurs deeper.

These size differences may also be due to intra-specific variation with different cohorts or growth rates, but are enhanced by variation in vesicomyid species dominance, which showed a clear shift between sites A and C dominated by C. regab (92-98\%) to site B dominated by A. southwardae (87\%). A. southwardae displays a more elongated morphology than C. regab (Krylova et al. 2010) and has larger individuals than $C$. regab in the lobe area (except at site C), which may confer an advantage for this species to reach deep sulfides. A. southwardae also differ from C. regab in terms of a better physiological adaptation for hypoxia, having hemoglobin with high oxygen affinity, likely allowing longer or deeper burrowing than C. regab (Decker et al., in press this issue). These contrasting properties likely involve differences in bio-irrigation and bioturbation efficiency and in the thickness of the sediment layer affected. Despite differences in other biological traits such as ability to move, higher growth and reproduction rates proposed to explain C. regab dominance (Decker et al., in press this issue; Guillon et al., 2017), the spatial heterogeneity of sulfide availability (Sen et al., accepted, this issue) and differences in present-day Congo inputs in the disconnected lobe B compared to the active lobes (Rabouille et al. in press this issue) likely favor one or another species to colonize each site first. Therefore, the observed geochemical gradients structuring macrofauna 


\section{ACCEPTED MANUSCRIPT}

communities likely result from environmental heterogeneity (level of sulfide availability and depth of sulfide production zone, that facilitates colonization by one species or another, and bio-irrigation effects of vesicomyids that further enhance the differences between sites

Turnover in polychaete families was also observed among vesicomyids in the Regab pockmark (Guillon et al., 2017) and was attributed to fluid flow variability and vesicomyid population characteristics (density, length and species composition). This pattern seems to be enhanced in the lobe area, where sulfide gradients, particularly the depth of maximum sulfide, and vesicomyid composition were more contrasted.

The high turnover of macrofauna across vesicomyid beds colonizing the Congo lobe area is therefore related to the high heterogeneity of geochemical gradients in this sulfide-rich habitat occurring at multiple spatial scales and driven by various environmental or biotic factors: the distribution of turbiditic material over the lobe complex (active lobe vs. partly disconnected lobe), the intensity of turbiditic currents and sediment reworking along the active lobe complex from channel entrance to the depositional area, but also the vesicomyids themselves, which modify geochemical gradients differently according to their density, size, and species.

Does spatial variability of macrofaunal community structure between habitats reflect community succession?

Observations based on macrofaunal community patterns, vesicomyid population characteristics, geochemical gradients and location within the lobe system may be interpreted as temporal evolution of these ephemeral chemosynthesis-based habitats (Fig. 8). Rapid succession is expected particularly in the youngest lobe presently receiving most of the turbiditic material at a high frequency (one event every 6 to 17 yrs according to (Dennielou et al., in press. this isssue). Burying is likely to occur as several tens of sediment may be deposited by one turbiditic event, the sedimentation rates of 12 - 


\section{ACCEPTED MANUSCRIPT}

$20 \mathrm{~cm} . y r-1$ being averaged rates over the last $100 \mathrm{yrs}$ (Rabouille et al., this issue). The duration of one particular habitat may be much less than whale falls where the sulfophilic stage may last several decades (Smith and Baco, 2003). Succession models at cold seeps (and at hydrothermal vents) start with colonization of sulfide-rich sediments by microbial mats (Bergquist et al., 2003b; Bowden et al., 2013; Cordes et al., 2005; Fischer et al., 2012). In the Congo lobe complex, the black patch of reduced sediment, where sulfide fluxes and concentrations were the highest can be assumed to be the first step of colonization by opportunistic, motile and sulfide-tolerant taxa, dorvilleids and hesionids polychaetes (see Levin 2005 and Jumars et al. 2015 for review) and hyalogirinid gastropods also colonizing microbial mats (e.g. Warén \& Bouchet 2009; Portail et al. 2015). Microbial mats may grow rapidly, but their development may be limited by the very dense population of hyalogirinid gastropod grazers as well as the mobile omnivores dorvilleid and hesionid polychaetes potentially feeding on these filamentous bacteria among other possible microbial or eukaryote preys (Levin et al. 2013; Jumars et al. 2015). Hesionids dominate in microbial mats, by possibly feeding also on another type of microbial population, such as those occurring anaerobically that they may access, together with dorvilleids by their digging abilities (both families have been found in the $5-10 \mathrm{~cm}$ depth sediment layer). Their ability to burrow and resist anoxia may allow them to start bio-irrigating the first centimeters of sediments whereas sulfide-oxidizers forming mats consume sulfides whose concentration in the upper centimeters decreases, thereby allowing settlement of vesicomyid juveniles. If conditions are favorable, this vesicomyid population grows, consumes sulfides and also maintains the sulfate pump by irrigation and sulfide production, whose levels go deeper to $6-7 \mathrm{~cm}$ depth due to vesicomyid bio-irrigation. Vesicomyid density is very high, but the upper centimeters are also colonized by tube building surface feeders ampharetids assumed to rely on both detritical organic matter and aerobic microbial communities (Pruski et al., accepted, this issue), while omnivorous hesionids are still abundant, likely relying on another microbial populations or eukaryote preys (Jumars et al., 2015). Diversity increases in this habitat, with a greater variety of trophic niches due to the bioturbating and bio-irrigating action of vesicomyids, that can also be completed in 


\section{ACCEPTED MANUSCRIPT}

subsurface by the tube-building ampharetids (Bowden et al., 2013). The two other vesicomyid clusters, at site A and B may represent later stages, with deeper sulfide layers, shifts from opportunistic and surface feeders to polychaetes able to dig deeper (spionids, cossurids) (Fig.4b; (Jumars et al., 2015; Levin et al., 2010) and finally dominance of peracarid crustaceans by increasing the distance from sulfide layers. These mild geochemical conditions, as well as lower turbiditic inputs (sedimentation rate half reduced compared to site $\mathrm{A}$, and 20 times less than at site $\mathrm{C}$ ), but without decrease in carbon content, likely allow greater diversity, as expected by the sharply increasing rarefaction curve and high richness despite undersampling. This latter community observed at site B was very similar to those inhabiting the adjacent sediments despite high sulfide concentrations found deeper than $15 \mathrm{~cm}$ depth. As mentioned above, the macrofauna community of the levee sediments is more closely related to low-flux cold-seep communities (such as the nearby Regab pockmark) than to a typical deep-sea community. There are clear similarities of the macrofaunal community structure between lobe chemosynthesis-based habitats and their counterparts of the Regab pockmark (at least at the family level) (Guillon et al., 2017; Menot et al., 2010) and habitat evolution (dynamics) may be similarly driven by the interplay of geochemical gradients, microbial communities, and vesicomyid consumption and bio-irrigation. However, limited resources in the lobe area compared with cold seeps fed by an oil or methane reservoir, may limit chemosynthesis ecosystems to short-lived habitats and rapid succession. Mapping the distribution of the different chemosynthesis-based habitats (Sen et al., accepted, this issue), highlighted the high proportion of reduced sediment patches uncolonized by vesicomyids in the area of main deposition at site $\mathrm{C}$, compared with levees at sites A and F. Nevertheless, environmental heterogeneity of the lobe area due to turbidite distribution (sedimentation rates) (Rabouille et al., in press this issue), lobe complex morphology (Dennielou et al., in press. this isssue), post-depositional sedimentary processing facilitating sulfide exhumation and chemosynthesis-based habitat distribution (Dennielou et al., in press. this isssue; Sen et al., accepted, this issue), sustain the establishment of different engineering vesicomyid species and highly diversified macrofaunal communities (gamma-diversity) at a regional 


\section{ACCEPTED MANUSCRIPT}

scale. High-frequency disturbances resulting from turbiditic events may also result in highly dynamic habitats with high turnover of macrofauna.

\section{Conclusion}

Similarly to cold seeps on pockmarks and whale or other vertebrate carcasses abundant in the Congo fan area (Higgs et al., 2014), export of terrestrial organic carbon by the Congo River helps sustain chemosynthesis production along the Congo margin down to its deepest depths. Geochemical resemblances between these sulfide-rich habitats lead to faunistic homologies and species sharing. Although less diversified than cold seeps (e.g. absence of carbonate and high fluxes creating gas bubbles), methane fluxes in reduced sediments of the Congo deep-sea fan were as high as in similar cold seeps habitats, may foster greater faunistic similarities of these habitats with cold seeps on pockmarks than with other organic deposits. This similarity suggests that there is a spatial and temporal continuum of cold-seep-like habitats between areas supplied by present or recent turbiditic deposits of the present Congo channel, and by older ones buried in deep paleo-channels and uplifted by tectonic movements, allowing maintenance and evolution of chemosynthesis-based fauna at a regional scale. Finally, if chemosynthesis sustains locally high biomass and acts as benthic filter for methane (Boetius and Wenzhöfer, 2013), chemosynthesis-based habitats are very patchily distributed and short-lived. In contrast, the remarkably high densities of the detritus-based macrofauna compared with background abyssal sediments may be a pervasive pattern in the whole lobe area fed by turbidites and therefore likely play a significant role in the carbon storage in the deep sediments.

\section{Acknowledgments}




\section{ACCEPTED MANUSCRIPT}

The authors would like to thank the captain and crews of the R/V Pourquoi Pas? and Victor 6000 for their assistance in operations and data collection during the Congolobe cruise. Cruise information (metadata, dive reports, videos, related publications) are available on the French Oceanographic cruises website at: http://dx.doi.org/10.17600/11030170. We thank also P. Noël for technical assistance for board operations. We are indebted to Manuela Rabiller and Olivier Mouchel for their help on board in sample processing. They were helped for fauna sorting in the lab by Meriem Ain Baziz Emmanuelle Omnes. We warmly thank Elena Krylova and Anders Wàren for their help in the identification of vesicomyids and hyalogirinids respectively. We would also like to thank the Congolobe working group, for fruitful discussions. Funding for this study was provided by the French National Agency for Research (ANR) Congolobe ANR Blanc SIMI5-6, no.11BS56030. The manuscript was professionally edited by Carolyn Engel-Gautier. We thank the 3 anonymous reviewers for their helpful comments on the manuscript.

\section{References}

Babonneau, N., Savoye, B., Cremer, M., Klein, B., 2002. Morphology and architecture of the present canyon and channel system of the Zaire deep-sea fan. Marine and Petroleum Geology 19, 445467.

Baco, A.R., C.R., S., Peek, A.S., Roderick, G.K., Vrijenhoek, R.C., 1999. The phylogenetic relationships of whale-fall vesicomyid clams based on mitochondrial COI DNA sequences. Marine Ecology Progress Series 182, 137-147.

Baudin, F., Disnar, J.-R., Martinez, P., Dennielou, B., 2010. Distribution of the organic matter in the channel-levees systems of the Congo mud-rich deep-sea fan (West Africa). Implication for the deep offshore petroleum source rocks and global carbon cycles. Marine and Petroleum Geology 27, 995-1010. 


\section{ACCEPTED MANUSCRIPT}

Baudin, F., Martinez, P., Dennielou, B., Charlier, K., Marsset, T., Droz, L., Rabouille, C., in press b. this issue. Organic carbon accumulation in modern sediments of the Angola basin influenced by the Congo deep sea fan. Deep Sea Research Part II: Topical Studies in Oceanography.

Baudin, F., Stetten, E., Schnyder, J., Charlier, K., Martinez, P., Dennielou, B., Droz, L., in press a. this issue. Origin and distribution of the organic matter in the distal lobe of the Congo deep-sea fan A Rock-Eval survey. Deep Sea Research Part II: Topical Studies in Oceanography.

Bergquist, D.C., Andras, J.P., McNelis, T., Howlett, S., van Horn, M.J., Fisher, C.R., 2003a. Succession in Gulf of Mexico Cold Seep vestimentiferan aggregations: the importance of spatial variability. P. S. Z. N. I: Marine Ecology 24, 31-44.

Bergquist, D.C., Ward, T., Cordes, E.E., McNelis, T., Howlett, S., Kosoff, R., Hourdez, S., Carney, R., Fisher, C.R., 2003b. Community structure of vestimentiferan-generated habitat islands from Gulf of Mexico cold seeps. Journal of Experimental Marine Biology and Ecology 289, 197-222.

Bessette, S., Moalic, Y., Gauthey, S., Lesongeur, F., Godfroy, A., Toffin, L., in prep. Abundance and distribution of aerobic methanotrophic communities at the oxic-anoxic interface in deep organicrich sediments of the Congo lobes.

Boetius, A., Wenzhöfer, F., 2013. Seafloor oxygen consumption fuelled by methane from cold seeps. Nature Geosciences 6, 725-734.

Boudreau, B.P., 1996. A method-of-lines code for carbon and nutrient diagenesis in aquatic sediments. Computers \& Geosciences 22, 479-496.

Bowden, D.A., Rowden, A.A., Thurber, A.R., Baco, A., Levin, L.A., Smith, C.R., 2013. Cold Seep Epifaunal Communities on the Hikurangi Margin, New Zealand: Composition, Succession, and Vulnerability to Human Activities. PloS One 8, e76869.

Caprais, J.C., Lanteri, N., Crassous, P., Noël, P., Bignon, L., Rousseaux, P., Pignet, P., Khripounoff, A., 2010. A new CALMAR benthic chamber operating by submersible: First application in the coldseep environment of Napoli mud volcano (Mediterranean Sea). Limnology and Oceanography: Methods 8, 304-312. 


\section{ACCEPTED MANUSCRIPT}

Cordes, E.E., Bergquist, D.C., Fisher, C., 2009. Macro-Ecology of Gulf of Mexico Cold Seeps. Annuual Review of Marine Sciences 1, 143-168.

Cordes, E.E., Hourdez, S., Predmore, B.L., Redding, M.L., Fisher, C.R., 2005. Succession of hydrocarbon seep communities associated with the long-lived foundation species Lamellibrachia luymesi. Marine Ecology Progress Series 305, 17-29.

Cosson, N., Sibuet, M., Galeron, J., 1997. Community structure and spatial heterogeneity of the deepsea macrofauna at three contrasting stations in the tropical northeast Atlantic. Deep-Sea Research Part I-Oceanographic Research Papers 44, 247-269.

de Beer, D., Sauter, E., Niemann, H., Kaul, N., Foucher, J.P., Witte, U., Schlüter, M., Boetius, A., 2006. In situ fluxes and zonation of microbial activity in surface sediments of the Hâkon Mosby mud volcano. Limnology and Oceanography 51, 1315-1331.

De Leo, F.C., Smith, C.R., Rowden, A.A., Bowden, D.A., Clark, M.R., 2010. Submarine canyons: hotspots of benthic biomass and productivity in the deep sea. Proceedings of the Royal Society B: Biological Sciences.

Decker, C., Caprais, J.-C., Khripounoff, A., Olu, K., 2012a. First respiration estimates of cold-seep vesicomyid bivalves from in situ total oxygen uptake measurements. Comptes Rendus Biologies $335,261-270$.

Decker, C., Morineaux, M., Van Gaever, S., Caprais, J.-C., Lichtschlag, A., Gauthier, O., Andersen, A.C., Olu, K., 2012b. Habitat heterogeneity influences cold-seep macrofaunal communities within and among seeps along the Norwegian margin. Part 1: macrofaunal community structure. Marine Ecology 33, 205-230.

Decker, C., Zorn, N., Le Bruchec, J., Caprais, J.C., Potier, N., Leize-Wagner, E., Lallier, F., Olu, K., Andersen, A., in press this issue. Can hemoglobin characteristics of vesicomyid clam species influence their distribution in deep-sea sulfide-rich sediments ? A case study in the Gulf of Guinea. Deep Sea Research II (Congolobe special issue). 


\section{ACCEPTED MANUSCRIPT}

Dennielou, B., Droz, L., Jacq, C., Babonneau, N., Bonnel, C., Picot, M., Le Saout, M., Saout, J., Bez, M., Savoye, B., Olu, K., Rabouille, C., in press. this isssue. Morphology, structure, composition and build-up processes of the active Congo channel-mouth lobe complex with inputs from remotely operated underwater vehicle (ROV) multibeam and video surveys. Deep Sea Research II Congolobe Special issue.

Dinet, A., Desbruyères, D., Khripounoff, A., 1985. Abondances des peuplements macro- et meiobenthiques: repartition et strategie d'echantillonnage., in: Laubier, L., Monniot, C. (Eds.), Peuplements profonds du golfe de Gascogne: campagnes BIOGAS. IFREMER Brest, pp. 121-142.

Distel, D.L., Baco, A.R., Chuang, E., Morrill, W., Cananaugh, C., Smith, C.R., 2000. Do mussel take wooden steps to deep-sea vents? Nature 403, 725.

Fischer, D., Sahling, H., Nöthen, K., Bohrmann, G., Zabel, M., Kasten, S., 2012. Interaction between hydrocarbon seepage, chemosynthetic communities and bottom water redox at cold seeps of the Makran accretionary prism: insights from habitat-specific pore water sampling and modeling. Biogeosciences 9, 2013-2031.

Gage, J.D., Lamont, P.A., Tyler, P.A., 1995. Deep-Sea Macrobenthic Communities at Contrasting Sites off Portugal, Preliminary Results: I Introduction and Diversity Comparisons. Internationale Revue der gesamten Hydrobiologie und Hydrographie 80, 235-250.

Galéron, J., Menot, L., Renaud, N., Crassous, P., Khripounoff, A., Treignier, C., Sibuet, M., 2009. Spatial and temporal patterns of benthic macrofaunal communities on the deep continental margin in the Gulf of Guinea. Deep Sea Research Part II: Topical Studies in Oceanography 56, $2299-2312$.

Gay, A., Lopez, M., Berndt, C., Seranne, M., 2007. Geological controls on focused fluid flow associated with seafloor seeps in the Lower Congo Basin. Marine Geology 244, 68-92.

Gay, A., Lopez, M., Cochonat, P., Seranne, M., Levache, D., Sermondadaz, G., 2006. Isolated seafloor pockmarks linked to BSRs, fluid chimneys, polygonal faults and stacked Oligocene-Miocene turbiditic palaeochannels in the Lower Congo Basin. Marine Geology 226, 25. 


\section{ACCEPTED MANUSCRIPT}

Gotelli, N.J., Colwell, R.K., 2001. Quantifying biodiversity: procedures and pitfalls inn the measurement and comparison of species richness. Ecology Letters 4, 379-391.

Guillon, E., Menot, L., Decker, C., Krylova, E., Olu, K., 2017. The vesicomyid bivalve habitat at cold seeps supports heterogeneous and 1 dynamic macrofaunal assemblages. Deep Sea Research I $120,1-13$.

Heussner, S., Durrieu de Madron, X., Calafat, A., Canals, M., Carbonne, J., Delsaut, N., Saragoni, G., 2006. Spatial and temporal variabilityof downward particle fluxes on acontinental slope: lessons from an 8-y rexperiment in the Gulf of Lions (NW Mediterranean). Marine Geology 234, 63-92.

Higgs, N.D., Gates, A.R., Jones, D.O.B., 2014. Fish food in the deep sea: revisiting the role of large food-falls. PloS One 9

Hurlbert, S.H., 1971. The Nonconcept of Species Diversity: A Critique and Alternative Parameters. Ecology 52, 577-586.

Iversen, N., Jorgensen, B.B., 1985. Anaerobic methane oxidation rates at the sulfate-methane transition in marine sediments from Kattegat and Skagerrak (Denmark). Limnology and Oceanography 30, 944-955.

Jumars, P.A., Dorgan, K.M., Lindsay, S.M., 2015. Diet of Worms Emended: An Update of Polychaete Feeding Guilds. Annu. Rev. Mar. Sci. 7, 497-520.

Khripounoff, A., Caprais, J.C., Crassous, P., 2006. Geochemical and biological recovery of the disturbed seafloor in polymetallic nodule fields of the Clipperton-Clarion Fracture Zone (CCFZ) at 5000m depth. , . Limnology and Oceanography 51, 2033-2041.

Khripounoff, A., Caprais, J.C., Decker, C., Essirard, M., Le Bruchec, J., Noel, P., Olu, K., 2015. Variability in gas and solute fluxes through deep-sea chemosynthetic ecosystems inhabited by vesicomyid bivalves in the Gulf of Guinea. Deep Sea Research Part I: Oceanographic Research Papers 95, 122130. 


\section{ACCEPTED MANUSCRIPT}

Khripounoff, A., Vangriesheim, A., Babonneau, N., Crassous, P., Dennielou, B., Savoye, B., 2003. Direct observation of intense turbidity current activity in the Zaire submarine valley at $4000 \mathrm{~m}$ water depth. Marine Geology 194, 151-158.

Kröncke, I., Türkay, M., 2003. Structural and functional aspects of the benthic communities in the deep Angola Basin. Marine Ecology Progress Series 260, 43-53.

Krylova, E., Sahling, H., Janssen, R., 2010. Abyssogena: a new genus of the family Vesicomyidae (Bivalvia) from deep-water vents and seeps. Journal of Molluscan Studies 76, 107-132.

Levin, L.A., 2005. Ecology of cold seep sediments: interactions of fauna with flow, chemistry and microbes. Oceanography and Marine Biology Annual Review 43, 1-46.

Levin, L.A., Mendoza, G.F., Gonzalez, J.P., Thurber, A.R., Cordes, E.E., 2010. Diversity of bathyal macrofauna on the northeastern Pacific margin: the influence of methane seeps and oxygen minimum zones. Marine Ecology 31, 94-110.

Levin, L.A., Sibuet, M., 2012. Understanding Continental Margin Biodiversity: A New Imperative. Annual Review of Marine Science 4, 79-112.

Levin, L.A., Ziebis, W., F. Mendoza, G., Bertics, V.J., Washington, T., Gonzalez, J., Thurber, A.R., Ebbe, B., Lee, R.W., 2013. Ecological release and niche partitioning under stress: Lessons from dorvilleid polychaetes in sulfidic sediments at methane seeps. Deep Sea Research Part II: Topical Studies in Oceanography 92, 214-233.

Levin, L.A., Ziebis, W., Mendoza, G.F., Growney, V.A., Tryon, M.D., Mahn, C., Gieskes, J.M., Rathburn, A.E., 2003. Spatial heterogeneity of macrofauna at northern California methane seeps: influence of sulfide concentration and fluid flow. MEPS 265, 123-139.

Menot, L., Galéron, J., Olu, K., Caprais, J.C., Crassous, P., Khripounoff, A., Sibuet, M., 2010. Spatial heterogeneity of macro-infaunal communities in and near a giant pockmark area in the deep Gulf of Guinea. Marine Ecology 31, 78-93. 


\section{ACCEPTED MANUSCRIPT}

Milliman, J.D., 1991. Flux and fate of fluvial sediment and water in coastal seas, in: Mantoura, R.F.C., Martin, J.-M., Wollast, R. (Eds.), Ocean Margin Processes in Global Change. Wiley and Sons, Berlin, pp. 69-91.

Mollenhauer, G., Schneider, R.R., Jennerjahn, T., Müller, P.J., Wefer, G., 2004. Organic carbon accumulation in the South Atlantic Ocean: its modern, mid-Holocene and last glacial distribution. Glob. Planet. Chang. 40, 249-266.

Niemann, H., Losekann, T., de Beer, D., Elvert, M., Nadalig, T., Knittel, K., Amann, R., Sauter, E.J., Schluter, M., Klages, M., Foucher, J.P., Boetius, A., 2006. Novel microbial communities of the Haakon Mosby mud volcano and their role as a methane sink. Nature 443, 854 .

Olu-Le Roy, K., Caprais, J.C., Fifis , A., Fabri , M.C., Galéron, J., Budzinski, H., Le Ménach, K., Khripounoff, A., Ondréas, H., Sibuet, M., 2007. Cold seep assemblages on a giant pockmark off West Africa: spatial patterns and environmental control. Marine Ecology 28, 115-130.

Olu, K., 2011. WACS cruise, RV Pourquoi pas ? http://dx.doi.org/10.17600/11030010.

Ondréas, H., Olu, K., Fouquet, Y., Charlou, J., Gay, A., Dennielou, B., Donval, J., Fifis, A., Nadalig, T., Cochonat, P., Cauquil, E., Bourillet, J., Moigne, M., Sibuet, M., 2005. ROV study of a giant pockmark on the Gabon continental margin. Geo-Marine Letters 25, 281.

Pastor, L., Toffin, L., Decker, C., Olu, K., Cathalot, C., Lesongeur, F., Caprais, J.C., Bessette, S., Brandily, C., Taillefert, M., Rabouille, C., in press, this issue. Early diagenesis in the sediments of the Congo deep-sea fan dominated by massive terrigenous deposits: Part III - Sulfate- and methane- based microbial processes. Deep Sea Research II Congolobe Special issue.

Paull, C.K., Schlining, B., Ussler, W., Lundste, E., Barry, J.P., al., e., 2010. Submarine mass transport within Monterey canyon: benthic disturbance controls on the distribution of chemosynthetic biological communities, in: D Mosher, C.S., L Moscardelli (Ed.), Submarine Mass Movements and Their Consequences. Springer, Dordrecht, Netherlands, pp. 229-246. 


\section{ACCEPTED MANUSCRIPT}

Pop Ristova, P., Wenzhöfer, F., Ramette, A., Zabel, M., Fischer, D., Kasten, S., Boetius, A., 2012. Bacterial diversity and biogeochemistry of different chemosynthetic habitats of the REGAB cold seep (West African margin, 3160 m water depth). Biogeosciences 9, 5031-5048.

Portail, M., Olu, K., Dubois, S.F., Escobar-Briones, E., Gelinas, Y., Menot, L., Sarrazin, J., 2016. FoodWeb Complexity in Guaymas Basin Hydrothermal Vents and Cold Seeps. PLoS ONE 11, e0162263.

Portail, M., Olu, K., Escobar-Briones, E., Caprais, J.C., Menot, L., Waeles, M., Cruaud, P., Sarradin, P.M., Godfroy, A., Sarrazin, J., 2015. Comparative study of vent and seep macrofaunal communities in the Guaymas Basin. Biogeosciences 12, 5455-5479.

Pozzato, L., Cathalot, C., Berrached, C., Toussaint, F., Stetten, E., Caprais, J.C., Pastor, L., OLu, K., Rabouille, C., subm. this issue. Early diagenesis in the Congo deep-sea fan sediments dominated by massive terrigenous deposits: Part I - Oxygen consumption and organic carbon mineralization using a micro-electrode approach. Deep Sea Research II Congolobe Special Issue.

Pruski, A.M., Decker, C., Stetten, E., Vétion, G., Martinez, P., Senyarich, C., Charlier, K., Olu, K., accepted, this issue. Energy transfer in the Congo turbiditic system: from terrestrially-derived organic matter to chemosynthetic food webs. Deep Sea Research II Congolobe Special Issue.

Puig, P., Ogston, A.S., Mullenbach, B.L., Nittrouer, C.A., Parsons, J.D., Sternberg, R.W., 2004. Storminduced sediment gravity flows at the head of the Eel submarine canyon, northern California margin. Journal of Geophysical Research: Oceans 109, n/a-n/a.

Rabouille, C., 2011. Congolobe cruise, RV Pourquoi pas ? http://dx.doi.org/10.17600/11030170.

Rabouille, C., Caprais, J.C., Lansard, B., Crassous, P., Dedieu, K., Reyss, J.L., Khripounoff, A., 2009. Organic matter budget in the Southeast Atlantic continental margin close to the Congo Canyon: In situ measurements of sediment oxygen consumption. Deep Sea Research Part II: Topical Studies in Oceanography 56, 2223-2238.

Rabouille, C., Olu, K., Baudin, F., Khripounoff, A., Dennielou, B., Arnaud-Haond, S., Babonneau, N., Bayle, C., Beckler, J., Bessette, S., Bombled, B., Bourgeois, S., Brandily, C., Caprais, J.C., Cathalot, C., Charlier, K., Corvaisier, R., Croguennec, C., Cruaud, P., Decker, C., Droz, L., Gayet, N., Godfroy, 


\section{ACCEPTED MANUSCRIPT}

A., Hourdez, S., Le Bruchec, J., Le Saout, J., Lesaout, M., Lesongeur, F., Martinez, P., Mejanelle, L., Michalopoulos, P., Mouchel, O., Noel, P., Pastor, L., Picot, M., Pignet, P., Pozzato, L., Pruski, A.M., Rabiller, M., Raimonet, M., Ragueneau, O., Reyss, J.L., Rodier, P., Ruesch, B., Ruffine, L., Savignac, F., Senyarich, C., Schnyder, J., Sen, A., Stetten, E., Sun, M.Y., Taillefert, M., Teixeira, S., TisneratLaborde, N., Toffin, L., Tourolle, J., Toussaint, F., Vétion, G., Jouanneau, J.M., Bez, M., in press this issue. The Congolobe project, a multidisciplinary study of Congo deep-sea fan lobe complex: Overview of methods, strategies, observations and sampling. Deep Sea Research Part II: Topical Studies in Oceanography Congolobe special Issue.

Ritt, B., Pierre, C., Gauthier, O., Wenzhöfer, F., Boetius, A., Sarrazin, J., 2011. Diversity and distribution of cold-seep fauna associated with different geological and environmental settings at mud volcanoes and pockmarks of the Nile Deep-Sea Fan. Marine Biology.

Rowe, G., Sibuet, M., Deming, J., Tietjen, J.H., Khripounoff, A., 1990. Organic carbon turnover time in deep-sea benthos. Progress In Oceanography 24, 141-160.

Rowe, G.T., Polloni, P.T., Haedrich, R.L., 1982. The deep-sea macrobenthos on the continental margin of the northwest Atlantic Ocean. Deep Sea Research Part A. Oceanographic Research Papers 29, 257-278.

Sahling, H., Bohrmann, G., Spiess, V., Bialas, J., Breitzke, M., Ivanov, M., Kasten, S., Krastel, S., Schneider, R., 2008. Pockmarks in the Northern Congo Fan area, SW Africa: Complex seafloor features shaped by fluid flow. Marine Geology 249, 206-225.

Sahling, H., Rickert, D., Lee, R.W., Linke, P., Suess, E., 2002. Macrofaunal community structure and sulfide flux at gas hydrate deposits from the Cascadia convergent margin, NE Pacific. Marine Ecology Progress Series 231, 121-138.

Samadi, S., Quéméré, E., Lorion, J., Tillier, A., von Cosel, R., Lopez, P., Cruaud, C., Couloux, A., Boisselier-Dubayle, M.-C., 2007. Molecular phylogeny in mytilids supports the wooden steps to deep-sea vents hypothesis. Comptes Rendus Biologies 330, 446-456. 


\section{ACCEPTED MANUSCRIPT}

Sasaki, T., Waren, A., Kano, Y., Okutani, T., Fujikura, K., 2010. Gastropods from recent hot vents and cold seeps: systematics, diversity and life strategies, The vent and seep biota. Springer, pp. 169254.

Savoye, B., Babonneau, N., Dennielou, B., Bez, M., 2009. Geological overview of the Angola-Congo margin, the Congo deep-sea fan and its submarine valleys. Deep Sea Research Part II: Topical Studies in Oceanography 56, 2169-2182.

Savoye, B., Cochonat, P., Apprioual, R., Bain, O., Baltzer, A., Bellec, V., Beuzart, P., Bourillet, J.F., Cagna, R., Cremer, M., Crusson, A., Dennielou, B., Diebler, D., Droz, L., Ennes, J.C., Floch, G., Guiomar, M., Harmegnies, F., Kerbrat, R., Klein, B., Kuhn, H., Landure , J.Y., Lasnier, C., LeDrezen, E., LeFormal, J.P., Lopez, M., Loubrieu, B., Marsset, T., Migeon, S., Norland, A., Nouze , H., Ondreas, H., Pelleau, P., Saget, P., Seranne, M., Sibuet, J.C., Tofani, R., Voisset, M., 2000. Structure et évolution récente de l'éventail turbiditique du Zaïre: premiers résultats scientifiques des missions d'exploration ZaïAngo 1\&2 (marge Congo-Angola). C. R. Acad. Sci. Paris, Sci. Ter. 331.

Sen, A., Dennielou, B., Tourolle, J., Arnaubec, A., Rabouille, C., Olu, K., accepted, this issue. Fauna and habitat types in the turbidity current driven Congo deep-sea fan lobes Deep Sea Research II (Congolobe special issue).

Sibuet, M., Olu-Le Roy, K., 2002. Cold Seep Communities on Continental Margins: Structure and Quantitative Distribution Relative to Geological and Fluid Venting Patterns, in: G. Wefer, D.B., D. Hebbeln, B.B. Jorgensen, T. Van Weering (Ed.), Ocean Margin Systems. Springer Verlag, Berlin, pp. 235-251.

Smith, C.R., Baco, A.R., 2003. Ecology of whale falls at the deep-sea floor, in: Gibson, R.N., Atkinson, R.J.A. (Eds.), Oceanography and Marine Biology, Vol 41, pp. 311-354.

Smith, C.R., Baco, A.R., Glover, A.G., 2002. Faunal succession on replicate deep-sea whale falls: time scales and vent-seep affinities. Cahiers de Biologie Marine 43, 291-297.

Smith, C.R., Kukert, H., Wheatcroft, R.A., Jumars, P.A., Deming, J.W., 1989. Vent fauna on whale remains. Nature 341, 27-28. 


\section{ACCEPTED MANUSCRIPT}

Soetaert, K., Heip, C., 1990. Soetaert, K. and Heip, C.: Sample-size dependence of diversity indices and the determination of sufficient sample size in a highdiversity deep-sea environment. Mar. Ecol. Prog. Ser 59, 305-307.

Soltwedel, T., Hasemann, C., Quéric, N.-V., von Juterzenka, K., 2005. Gradients in activity and biomass of the small benthic biota along a channel system in the deep Western Greenland Sea. Deep Sea Research Part I: Oceanographic Research Papers 52, 815-835.

Stetten, E., Baudin, F., Reyss, J.-L., Martinez, P., Charlier, K., Schnyder, J., Rabouille, C., Dennielou, B., Coston-Guarini, J., Pruski, A.M., 2015. Organic matter characterization and distribution in sediments of the terminal lobes of the Congo deep-sea fan: Evidence for the direct influence of the Congo River. Marine Geology 369, 182-195.

Taillefert, M., Beckler, C., Cathalot, C., Michalopoulos, P., Corvaisier, R., Kiriazis, N., Caprais, J.C., Pastor, L., Rabouille, C., subm. this issue. Early diagenesis in the sediments of the Congo deep-sea fan dominated by massive terrigenous deposits: Part II - Iron-sulfur coupling. Deep Sea Research II Congolobe special issue.

Teixeira, S., Olu, K., Decker, C., Cunha, R.L., Fuchs, S., Hourdez, S., Serrão, E.A., Arnaud-Haond, S., 2013. High connectivity across the fragmented chemosynthetic ecosystems of the deep Atlantic Equatorial Belt: efficient dispersal mechanisms or questionable endemism? Molecular Ecology 22, 4663-4680.

Thurber, A.R., Levin, L.A., Orphan, V.J., Marlow, J., 2012. Archaea in metazoan diets:implications for food webs and biogeochemical cycling. ISME 6, ,1610-1612.

Thurber, A.R., Levin, L.A., Rowden, A.A., Sommer, S., Linke, P., Kröger, K., 2013. Microbes, macrofauna, and methane: A novel seep community fueled by aerobic methanotrophy. Limnology and Oceanography 58, 1640-1656.

Treignier, C., Derenne, S., Saliot, A., 2006. Terrestrial and marine $\mathrm{n}$-alcohol inputs and degradation processes relating to a sudden turbidity current in the Zaire canyon. Organic Geochemistry 37, 1170-1184. 
Van Gaever, S., Galéron, J., Sibuet, M., Vanreusel, A., 2009a. Deep-sea habitat heterogeneity influence on meiofaunal communities in the Gulf of Guinea. Deep Sea Research Part II: Topical Studies in Oceanography 56, 2259-2269.

Van Gaever, S., Olu, K., Derycke, S., Vanreusel, A., 2009b. Metazoan meiofaunal communities at cold seeps along the Norwegian margin: Influence of habitat heterogeneity and evidence for connection with shallow-water habitats. Deep Sea Research Part I: Oceanographic Research Papers 56, 772-785.

Vangriesheim, A., Khripounoff, A., Crassous, P., 2009. Turbidity events observed in situ along the Congo submarine channel. Deep Sea Research Part II: Topical Studies in Oceanography 56, 22082222.

Vangriesheim, A., Treguier, A.M., Andre, G., 2005. Biweekly current oscillations on the continental slope of the Gulf of Guinea. Deep Sea Research I 52, 2168-2183.

Vetter, E.W., Dayton, P.K., 1998. Macrofaunal communities within and adjacent to a detritus-rich submarine canyon system. Deep-Sea Res. Part II 45, 25-54.

Vetter, E.W., Smith, C.R., De Leo, F.C., 2010. Hawaiian hotspots: enhanced megafaunal abundance and diversity in submarine canyons on the oceanic islands of Hawaii. Marine Ecology 31, 183-199.

Warén, A., Bouchet, P., 2009. New gastropods from deep-sea hydrocarbon seeps off West Africa. Deep Sea Research Part II: Topical Studies in Oceanography 56, 2326-2349.

Weaver, P.P.E., Billett, D.S.M., Boetius, A., Danovaro, R., Freiwald, A., sibuet, M., 2004. Hotspot ecosysem research on Europe's deep-ocean margins. Oceanography 17, 132-143.

Wenzhöfer, F., Glud, R.N., 2002. Benthic carbon mineralization in the Atlantic: a synthesis based on in situ data from the last decade. Deep Sea Research I 49, 1255-1279.

\section{Figure Caption}




\section{ACCEPTED MANUSCRIPT}

Figure 1. Map of the studied sites in the Congo terminal lobe complex. The different lobes are separated by dashed lines and numbered from the oldest (1) to the youngest (5) according to Babonneau et al.(2002). The dotted line in lobe 5 corresponds to the deposition zone with the highest measured sedimentation rates. Location of markers and respirometer (RAP) deployments. Usnel cores were taken at the same stations than RAP ones. Modified from Rabouille et al. (this issue).

Figure 2. Habitats sampled by ROV blade cores. a: Vesicomyid bed at site A (VesA), b: Vesicomyid bed at site $B($ VesB), c: reduced sediment at site C (RedC), d: microbial mat at site C, e: vesicomyid bed at site $\mathrm{C}(\mathrm{Ves})$, f: microbial mat and vesicomyids at site $\mathrm{F}(\mathrm{MmVesF})$; $\mathbf{g}$ : close up view of a microbial mat (MmC); $\mathbf{h}$ : close-up view of vesicomyids and ampharetids at VesC.

Figure 3. Macrofaunal composition and densities at the different sampling sites and habitats. Individual replicates are given by blade core number (see Table 1).

Figure 4. A. Vertical distribution of total macrofauna of each habitat (see Table 1 for sampling site and habitat information). Densities were averaged in each habitat. B. Vertical distribution of polychaete families in each sample. Densities were averaged by family considering all samples

Figure 5. Rarefaction curves showing the expected number of polychaete families in the different habitats sampled as a function of the number of sampled individuals

Figure 6. Principal component analysis based on Hellinger distance showing the ordination of samples according to their macrofaunal composition. All habitats and core replicates were included. The circle of equilibrium contribution indicates the significant contribution of the taxa with arrows longer than the radius.

Figure 7: Canonical redundancy analysis performed on the matrix of Hellinger-transformed macrofaunal densities averaged by habitat and the matrix of environmental factors. A. All habitats. The RDA is significant (ancova, $p=0.005$ ). B. Chemosynthesis-based habitats and adjacent sediments. The RDA was significant (ancova, $\mathrm{p}=0.007$ ). $\mathrm{H}_{2} \mathrm{~S} \_1 \mathrm{~cm}=\mathrm{H}_{2} \mathrm{~S}$ concentration at $1 \mathrm{~cm}$ below the seafloor; $\mathrm{H}_{2} \mathrm{~S}$ _flux: $\mathrm{H}_{2} \mathrm{~S}$ flux estimated from core gradients; ODP: Oxygen Penetration Depth; $\mathrm{SO}_{4}$ min=minimal sulfate concentration in the core; $\mathrm{SO}_{4}$ mindep=depth of minimal sulfate concentration; $\mathrm{H}_{2} \mathrm{~S} \_$maxdep $=$depth of maximal sulfide concentration. 


\section{ACCEPTED MANUSCRIPT}

Figure 8. Spatial heterogeneity and hypothetical dynamics (from Reduced sediment to Vesicomyid bed at site B) of chemosynthesis-based macrofauna in relation to changes in sulfide distribution related to vesicomyid bivalve bio-irrigation. The short shell vesicomyid is $C$. regab dominating in vesicomyid habitats at sites $A$ and $C$ and the long-shell one is $A$. southwardae, dominating the vesicomyid habitat at site $B$. The longest are the vesicomyid shells; the deepest is the sulfide maximal concentration. Dominant macrofauna taxa are indicated in each habitat, the highest dominant first (e.g. Hyalogirinidae in RedC). Macrofauna diversity increases from Reduced sediment to vesicomyid bed habitats.. Red. Sed.: reduced sediment (represented by RedC in the present study); Micr.mat=microbial mat ( $\mathrm{MmC}$ in the present study).

Table 1. Sample locations, depth and replicates. * Blade core sub-sampling of USNEL cores. USNEL cores were taken at the same location than RAP (respirometers). See Figure 1 and Rabouille et al. (in press, this issue) for Marker locations.

\begin{tabular}{|c|c|c|c|c|c|c|c|}
\hline Site & Latitude & Longitude & $\begin{array}{l}\text { Depth } \\
\text { (m) }\end{array}$ & Habitats & $\begin{array}{c}\text { Station } \\
\text { name }\end{array}$ & $\begin{array}{l}\text { Number of samples } \\
\text { (Blade cores) }\end{array}$ & Marker \\
\hline \multirow{3}{*}{ A } & & & & Vesicomyid bed & התכשר & 3 & Col 2 \\
\hline & $\begin{array}{c}56 \\
28.284\end{array}$ & E $6^{\circ} 2,145$ & 4770 & & & & \\
\hline & & & & $\begin{array}{l}\text { Adjacent } \\
\text { sediment }\end{array}$ & $\operatorname{Adj} A$ & 1 & Col 2 \\
\hline \multirow[t]{2}{*}{ B } & $\begin{array}{c}S 6^{\circ} \\
25,400\end{array}$ & $\begin{array}{c}\mathrm{E} \mathrm{5}^{\circ} \\
49,817\end{array}$ & 4833 & Vesicomyid bed & VesB & 3 & Col 11 \\
\hline & & & & $\begin{array}{l}\text { Reduced } \\
\text { sediment }\end{array}$ & RedC & 3 & Col 8 \\
\hline \multirow{4}{*}{ C } & $56^{\circ}$ & $E 5^{\circ}$ & & Microbial mats & $\mathrm{MmC}$ & 3 & Col 4 \\
\hline & 41,397 & 29,023 & jo & Vesicomyid bed & VesC & 3 & Col 9 \\
\hline & & & & $\begin{array}{l}\text { Adjacent } \\
\text { sediment }\end{array}$ & AdjC & 2 & Col 9 \\
\hline & & & & Levee & LevC & $2^{*}$ & Col-RAP3 \\
\hline E & $\begin{array}{c}S 6^{\circ} \\
5,353\end{array}$ & $\begin{array}{c}E 5^{\circ} \\
54,522\end{array}$ & 4768 & Reference & RefE & 3 & No marker \\
\hline \multirow[t]{2}{*}{$\mathbf{F}$} & $\begin{array}{c}56^{\circ} \\
35,431\end{array}$ & $\begin{array}{c}\text { E 5 } \\
41,412\end{array}$ & 4899 & $\begin{array}{l}\text { Microbial mats } \\
\text { and } \\
\text { vesicomyids }\end{array}$ & MmVesF & 3 & Col 3 \\
\hline & & & & Levee & LevF & $2^{*}$ & Col-RAP2 \\
\hline
\end{tabular}

Table 2. Mean density (ind. $\mathrm{m}^{-2}$ ) and its standard deviation (in parentheses) of macrofauna observed in all fractions ( $1 \mathrm{~mm}, 500 \mu \mathrm{m}, 300 \mu \mathrm{m}, 250 \mu \mathrm{m}$ mesh sizes) from the habitats sampled in the five lobes of the Congo deep-sea fan. (Ves = Vesicomyid bed, $\mathrm{Mm}=$ microbial mats, $\mathrm{Adj}=$ adjacent sediment, Red $=$ reduced sediment, Ref $=$ reference, Lev=channel levee, $\mathrm{nb}$ pol families = number of polychaete families, $\mathrm{ES}_{50}=$ Hurlbert; $\mathrm{H}^{\prime}=$ Shannon-Wiener, $\mathrm{J}^{\prime}=$ Pielou indexes) 


\begin{tabular}{|c|c|c|c|c|c|c|c|c|c|c|c|}
\hline & \multicolumn{4}{|c|}{ Site B } & \multirow{2}{*}{\multicolumn{4}{|c|}{ Site C }} & \multirow{4}{*}{$\begin{array}{l}\text { Sit } \\
\text { e E }\end{array}$} & \multicolumn{2}{|c|}{ Site F } \\
\hline & \multicolumn{2}{|c|}{ Site A } & & & & & & & & & \\
\hline & & Adj & & \multirow[b]{2}{*}{ RedC } & \multirow[b]{2}{*}{$\mathrm{MmC}$} & \multirow[b]{2}{*}{ VesC } & \multirow[b]{2}{*}{ AdjC } & \multirow[b]{2}{*}{ Levc } & & \multirow{2}{*}{$\begin{array}{c}\text { MmV } \\
\text { esF }\end{array}$} & \multirow{2}{*}{$\begin{array}{c}\text { Lev } \\
\text { F }\end{array}$} \\
\hline & VesA & A & VesB & & & & & & & & \\
\hline \multicolumn{12}{|l|}{ Bivalvia } \\
\hline & & & & & 7513 & 506 & 165 & & 0 & 0 & 0 \\
\hline Vesicomyidae & 0 & 0 & 22 (19) & 11 (19) & (10297) & (605) & (233) & 0 & & & \\
\hline Nuculanidae & $22(38)$ & 0 & 0 & 0 & 0 & 0 & 0 & 0 & 0 & 0 & 0 \\
\hline \multirow[t]{3}{*}{ Solemyidae } & 0 & 0 & 22 (19) & 0 & 0 & 0 & 0 & 0 & 0 & 0 & 0 \\
\hline & & & & & & & & & 33 & 0 & 0 \\
\hline & & & & & & & & & (75 & & \\
\hline \multirow[t]{3}{*}{ Thyasiridae } & 0 & 0 & 0 & 0 & $51(76)$ & $44(76)$ & 0 & 0 & 7) & & \\
\hline & & & & & & & & & 66 & 924 & 132 \\
\hline & 110 & & 715 & & & 143 & 644 & & (0) & (280) & (14 \\
\hline ind. & (116) & 165 & (1067) & 264 (184) & 89 (69) & (163) & (910) & $33(0)$ & & & 0) \\
\hline \multicolumn{12}{|l|}{ Gastropoda } \\
\hline Phymorynchu & & & & & & & & & 0 & 0 & 0 \\
\hline s & 0 & 0 & 0 & 0 & 13 (19) & 0 & 0 & 0 & sing & & \\
\hline Hyalogyrinida & & & & 41,562 & 6980 & 506 & & & 0 & 149 & 0 \\
\hline e & $22(38)$ & 0 & 0 & (18965) & (8567) & (877) & 0 & 0 & 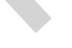 & (163) & \\
\hline ind. & 0 & 0 & 0 & 0 & 0 & 0 & 0 & 0 & 0 & 0 & 0 \\
\hline & & & & & & & & & $\begin{array}{c}33 \\
(57\end{array}$ & 0 & 0 \\
\hline Brachipoda & 0 & 0 & 0 & 0 & 0 & 0 & 0 & 0 & ) & & \\
\hline Crustacea & & & & & & & & & & & \\
\hline & & & & & & & & & 22 & 0 & 0 \\
\hline & & & & & & & & & (38 & & \\
\hline Amphipoda & 0 & 0 & 0 & 0 & 0 & 0 & 0 & 0 & ) & & \\
\hline & & & 396 & & & & & 132 & 0 & 17 & 116 \\
\hline Cumacea & 0 & 231 & (66) & 0 & 0 & 0 & $66(47)$ & (140) & & (23) & (23) \\
\hline & & & & & & & & & 33 & 33 & 594 \\
\hline & 110 & & 2530 & & & & 594 & & (33 & & (73 \\
\hline Isopoda & (76) & 429 & (458) & $22(19)$ & 102 (152) & 0 & (840) & $50(23)$ & 1 & & 7) \\
\hline & & & & & & & & & 0 & 0 & 17 \\
\hline Mysida & 0 & 0 & 0 & 0 & 0 & 0 & 0 & 0 & & & (23) \\
\hline & & & & & & & & & 14 & 0 & 743 \\
\hline & & & & & & & & & 3 & & (49 \\
\hline & & 138 & 1441 & & & & 2508 & 3614 & (13 & & 0) \\
\hline Tanaidacea & $11(19)$ & 6 & (364) & 0 & $51(88)$ & $88(50)$ & (3080) & (397) & 3) & & \\
\hline & & & & & & & & & 44 & 0 & 0 \\
\hline & & & & & & & & & (38 & & \\
\hline ind. & 0 & 0 & 0 & 0 & $13(32)$ & 0 & 0 & 0 & ) & & \\
\hline Polychaeta & & & & & & & & & & & \\
\hline & & & & & & & & & 11 & 0 & 0 \\
\hline & & & & & & & & & (19 & & \\
\hline Acrocirridae & 0 & 0 & 0 & 0 & 0 & 0 & 0 & 0 & ) & & \\
\hline Ampharetida & 110 & & & & & 2090 & & & 0 & 99 & 0 \\
\hline $\mathrm{e}$ & (137) & 0 & 0 & 11 (19) & $165(65)$ & (269) & $17(23)$ & 0 & & (47) & \\
\hline & & & & & & & & & 11 & 462 & 0 \\
\hline & 154 & & & & & & 99 & & (19 & (327) & \\
\hline Capitellidae & (239) & 0 & 0 & $22(38)$ & 723 (99) & 99 (33) & (140) & 0 & 1 & & \\
\hline & & & & & & & & & 11 & 0 & 447 \\
\hline & 1023 & 514 & 1441 & & & 110 & 2376 & 2640 & (19 & & 2 \\
\hline Cossuridae & (343) & 9 & (1023) & 0 & 0 & (191) & (327) & (933) & 1 & & $(10$ \\
\hline
\end{tabular}




\begin{tabular}{|c|c|c|c|c|c|c|c|c|c|c|c|}
\hline & & & & & & & & & & & 03) \\
\hline & & & & & & & & & 11 & 1023 & 0 \\
\hline & & & & 15,314 & 4822 & 297 & & & (19 & $(280)$ & \\
\hline Dorvilleidae & 0 & 0 & 44 (19) & (4279) & (4484) & (432) & $17(23)$ & 0 & 1 & & \\
\hline Euphosinidae & 0 & 0 & 0 & $22(19)$ & 0 & 0 & 0 & 0 & 0 & 0 & 0 \\
\hline & & & & & & & & & 11 & 0 & 0 \\
\hline Fauveliopsida & & & & & & & & & (19 & & \\
\hline e & 0 & 0 & 0 & 0 & 0 & 0 & 0 & 0 & ) & & \\
\hline & & & & & & & & & 11 & 0 & 0 \\
\hline Flabelligerida & & & & & & & & & (19 & & \\
\hline e & 0 & 0 & 0 & 0 & 0 & 0 & 0 & 0 & ) & & \\
\hline & & & & & & & & & 77 & 0 & 0 \\
\hline & & & & & & & & & (38 & & \\
\hline Glyceridae & 0 & 0 & 0 & 0 & 0 & 0 & 0 & 0 & 1 & & \\
\hline Goniadidae & 0 & 0 & $44(50)$ & 0 & 0 & 0 & 0 & $33(0)$ & 0 & 0 & 0 \\
\hline & & & & & & & & & 0 & 1381 & 0 \\
\hline & & & & & & & & & & 2 & \\
\hline & 858 & & & 8229 & 20901 & 3696 & 1155 & & & (1470 & \\
\hline Hesionidae & (381) & 99 & 0 & (936) & $(12,190)$ & (1516) & $(47)$ & $66(0)$ & & 1 & \\
\hline Lumbrinerida & & & & & & & & & 138 & (23) & (23) \\
\hline $\mathrm{e}$ & 0 & 0 & 0 & 0 & 0 & 0 & 0 & 0 & 1 & & \\
\hline & & & & & & & & & 0 & 0 & 33 \\
\hline Maldanidae & 0 & 0 & 0 & 0 & 0 & 0 & 0 & 0 & & & (47) \\
\hline Nautiliniellida & 110 & & & & & 286 & & & 0 & 0 & 0 \\
\hline e & (50) & 0 & 0 & 11 (19) & 0 & $(188)$ & 0 & 0 & & & \\
\hline & & & & & & & & & 11 & 0 & 0 \\
\hline & & & & & & & & & (19 & & \\
\hline Nereididae & 11 (19) & 0 & 0 & 0 & 0 & $33(33)$ & 0 & 0 & 1 & & \\
\hline & & & & & & & & & 11 & 0 & 0 \\
\hline & & & & & & & & & (19 & & \\
\hline Opheliidae & 0 & 0 & 0 & 0 & 0 & 0 & 0 & 0 & ) & & \\
\hline & & & & & & & & & 88 & 0 & 0 \\
\hline & & & & & & & & & $(38$ & & \\
\hline Paranoidae & 0 & 0 & $99(33)$ & 0 & 0 & 0 & 0 & 0 & 1 & & \\
\hline & & & & & & 264 & & & 0 & 33 & 83 \\
\hline Phyllodocidae & 55 (19) & 0 & $11(19)$ & 0 & 0 & (372) & 0 & 0 & & (47) & (70) \\
\hline & & & & & & & & & 22 & 0 & 0 \\
\hline & & & & & & & & 165 & (19 & & \\
\hline Pilargidae & 0 & 0 & 11 (19) & 0 & 0 & 0 & 0 & (93) & 1 & & \\
\hline Polynoidae & $33(33)$ & 0 & 0 & 0 & 0 & $55(38)$ & $17(23)$ & 0 & 0 & 0 & 0 \\
\hline & & & & & & & & & 0 & 0 & 66 \\
\hline Sabellidae & $11(19)$ & 0 & 11 (19) & 0 & 0 & 0 & 0 & 0 & & & (47) \\
\hline Scalibregmati & & & & & & & & & 0 & 0 & 0 \\
\hline dae & 0 & 0 & $11(19)$ & 0 & 0 & 0 & $17(23)$ & $66(93)$ & & & \\
\hline & & & & & & & & & 11 & 0 & 0 \\
\hline & & & & & & & & & (19 & & \\
\hline Sigalionidae & 0 & 0 & 0 & 0 & 0 & 0 & 0 & 0 & 1 & & \\
\hline & & & & & & & & & 44 & 2030 & 479 \\
\hline & 1133 & & 231 & & 1104 & 495 & 941 & 726 & (76 & $(2264$ & $(25$ \\
\hline Spionidae & (917) & 363 & $(184)$ & 121 (69) & (777) & $(486)$ & (303) & (47) & 1 & 1 & 7) \\
\hline & & & & & & & & & 33 & 0 & 0 \\
\hline & & & & & & & & & (33 & & \\
\hline Syllidae & 0 & 0 & 0 & 0 & 0 & 0 & 0 & 0 & 1 & & \\
\hline Terebellidae & 0 & 0 & $11(19)$ & 0 & 0 & 0 & 0 & 0 & 0 & 0 & 0 \\
\hline Trichobranchi & & & & & & & & & 0 & 0 & 0 \\
\hline dae & 0 & 0 & 11 (19) & 0 & 0 & 0 & 0 & 0 & & & \\
\hline
\end{tabular}




\begin{tabular}{|c|c|c|c|c|c|c|c|c|c|c|c|}
\hline & & & & & & & & & 11 & 0 & 0 \\
\hline & & & 121 & & & & & 231 & (19 & & \\
\hline \multirow[t]{4}{*}{ unidentified } & $22(38)$ & 99 & (125) & 0 & 0 & 0 & $17(23)$ & (327) & ) & & \\
\hline & & & & & & & & & 16 & 0 & 0 \\
\hline & & & & & & & & & 5 & & \\
\hline & & & & & & & & & 125 & & \\
\hline \multirow[t]{3}{*}{ juvenile } & 0 & 0 & 0 & 0 & 0 & 0 & 0 & 0 & 8) & & \\
\hline & & $79 ?$ & & & & & & & 10 & 18,03 & 676 \\
\hline & 3795 & 192 & 7173 & 65,589 & 42,525 & 8713 & 8630 & 7756 & 01 & 6 & 6 \\
\hline Mean density & $(372)$ & & (1060) & (20830) & (26169) & $(2230)$ & (3851) & $(560)$ & $(24$ & $(4037$ & (56 \\
\hline (s.d.) & & & & & & & & & ) & 1 & 0) \\
\hline $\begin{array}{l}\text { S (nb pol } \\
\text { families) }\end{array}$ & 10 & 3 & 11 & 7 & 5 & 10 & 8 & 6 & 15 & 7 & 6 \\
\hline $\mathrm{ES}_{50}$ & 7.1 & 3.3 & 7.0 & 2.4 & 3.9 & 7.1 & 4.6 & 5.5 & $\begin{array}{c}15 . \\
8\end{array}$ & 4.1 & 3.7 \\
\hline $\mathrm{H}^{\prime}$ & 1.6 & $\begin{array}{c}0.4 \\
1\end{array}$ & 1.14 & 0.70 & 0.77 & 1.44 & 1.19 & 1.06 & $\begin{array}{c}1.0 \\
6\end{array}$ & 0.75 & $\begin{array}{c}0.5 \\
4\end{array}$ \\
\hline $\mathrm{J}^{\prime}$ & 0.67 & $\begin{array}{c}0.3 \\
0\end{array}$ & 0.46 & 0.36 & 0.48 & 0.62 & 0.54 & 0.54 & $\begin{array}{c}0.3 \\
7\end{array}$ & 0.38 & $\begin{array}{c}0.2 \\
8\end{array}$ \\
\hline
\end{tabular}

Table 3. Values of the chemical parameters measured in all habitats and used as explanatory variables in the RDA 1 (All stations) and RDA 2 ("habitats"). Maximum values are in bold. $\mathrm{H}_{2} \mathrm{~S} \_1 \mathrm{~cm}=$ $\mathrm{H}_{2} \mathrm{~S}$ concentration at $1 \mathrm{~cm}$ below the seafloor; $\mathrm{H}_{2} \mathrm{~S}$-max: maximal concentration of $\mathrm{H}_{2} \mathrm{~S}$ in the core; ODP: Oxygen Penetration Depth; $\mathrm{SO}_{4}$ mindep=depth of minimal sulfate concentration; $\mathrm{H}_{2} \mathrm{~S}$ _flux: $\mathrm{H}_{2} \mathrm{Sflux}$ estimated from core gradients; $\mathrm{SO}_{4}$ min=minimal sulfate concentration in the core. For RDA 2 only $\mathrm{H}_{2} \mathrm{~S} \_1 \mathrm{~cm} ; \mathrm{H}_{2} \mathrm{~S}$ flux ; $\mathrm{SO}_{4}$ min and $\mathrm{H}_{2} \mathrm{~S} \_$maxdep= depth of maximal sulfide concentration were included in the analysis. n.d.: no data.

\begin{tabular}{|c|c|c|c|c|c|c|c|}
\hline & $\begin{array}{l}\mathbf{H}_{2} \mathbf{S} \_\mathbf{1 c m} \\
\mu \mathrm{mol} . \mathrm{l}-1 \\
\end{array}$ & $\begin{array}{l}\mathrm{H}_{2} \mathrm{~S} \_ \text {max } \\
\mu \mathrm{mol} . \mathrm{I}-1\end{array}$ & $\begin{array}{l}\text { ODP } \\
\mathrm{mm}\end{array}$ & $\begin{array}{c}\mathrm{SO}_{4 \_} \text {mindep } \\
\mathrm{cm}\end{array}$ & $\begin{array}{c}\mathbf{H}_{\mathbf{2}} \mathbf{S} \text { _flux } \\
\text { mmol.m- }{ }^{2} \cdot \mathrm{d}-1\end{array}$ & $\begin{array}{l}\mathrm{SO}_{4 \_ \text {min }} \\
\mathrm{mmol.l}-1\end{array}$ & $\begin{array}{c}\mathrm{H}_{2} \mathrm{~S} \_ \text {maxdep } \\
\mathrm{cm}\end{array}$ \\
\hline VesA & 8.315 & 8167.91 & 0.08 & 9.75 & 8.1 & 13.88 & 9.0 \\
\hline AdjA & 0 & 25.25 & 0.265 & 13.0 & 0.03 & 26.0 & 13.0 \\
\hline VesB & 0.0 & 2645.97 & 0.74 & 14.5 & 4.56 & 9.8 & 17.00 \\
\hline RedC & 8.47 & 5920 & 0.13 & 9.0 & 22.63 & 0.73 & 5.0 \\
\hline $\mathrm{MmC}$ & 1.27 & 133.79 & 0.5 & 11.0 & 1.57 & 5.45 & 11.0 \\
\hline VesC & 1 & 2235.18 & 0.16 & 7.33 & 4.27 & 7.47 & 7.0 \\
\hline AdjC & 1.37 & 1.44 & 0.88 & 20.0 & 0.0 & 16.0 & 15.0 \\
\hline LevC & 0.36 & 3.5925 & 1.57 & 7.5 & 0.0 & 23.93 & n.d. \\
\hline RefE & 0.0 & 0.0 & 5.43 & 18.0 & 0.0 & 26.48 & n.d. \\
\hline MmVesF & 136.08 & 1416.86 & 0.36 & 8.0 & 3.93 & 0.88 & 2.5 \\
\hline LevF & 0.63 & 2.19 & 1.36 & 16.0 & 0.0 & 21.14 & n.d. \\
\hline
\end{tabular}




\section{ACCEPTED MANUSCRIPT}

Table 4: Vesicomyid population characteristics at each habitat dominated by these bivalves.

C.r. $=$ Christineconcha regab. A.s. $=$ Abyssogena southwardae

\begin{tabular}{|c|c|c|c|c|c|c|c|}
\hline Site & 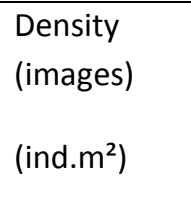 & $\begin{array}{l}\text { Density in } \\
\text { cores } \\
\text { (ind. }{ }^{2} \text { ) }\end{array}$ & $\begin{array}{l}\text { Proportion of } \\
\text { C. regab } \\
\text { (\%) }\end{array}$ & $\begin{array}{l}\mathrm{Nb} \text { measured } \\
\text { Specimens } \\
\text { (Cr/As) }\end{array}$ & $\begin{array}{c}\text { Mean size C. } r \text {. } \\
(\mathrm{mm})\end{array}$ & $\begin{array}{l}\text { Mean size } \\
\text { A. s. } \\
(\mathrm{mm})\end{array}$ & $\begin{array}{l}\text { Mean } \\
\text { size both } \\
\text { spp.(mm } \\
\text { ) }\end{array}$ \\
\hline VesA & 566 (261) & 814 (326) & 92 & $138 / 9$ & $73.2(8.9)$ & $122.3(18.7)$ & 77.1 \\
\hline VesB & $91(30)$ & 0 & 13 & $9 / 28$ & $70.5(4.8)$ & 121.4 (15.4) & 114.8 \\
\hline VesC & 1166 (361) & 1386 (429) & 98 & $230 / 4$ & $60.2(11.5)$ & $52.7(2.8)$ & 59.1 \\
\hline MmVesF & $26(15)$ & 0 & 61 & $11 / 6$ & $64.8(5.6)$ & $101.3(13.8)$ & 79.0 \\
\hline
\end{tabular}




\section{ACCEPTED MANUSCRIPT}

Table 5: Oxygen demand measured using benthic chambers manipulated by the ROV (Calmar) or from the ship (RAP) and macrofaunal density (see Tab. 2 for standard deviations).

Site

$\begin{array}{lll}\begin{array}{l}\text { Total oxygen } \\ \text { uptake }\end{array} & \begin{array}{l}\text { Macrofaunal } \\ \text { density }\end{array} & \begin{array}{l}\text { Benthic } \\ \text { chamber }\end{array}\end{array}$

$\left(m m o l . m^{-2} \cdot d^{-1}\right) \quad$ (ind. $\left.m^{-2}\right)$

$\begin{array}{llll}\text { Lev A } & -5.4 \pm 0.5 & \text { No data } & \text { RAP 1 } \\ \text { AdjA } & -6.5 & 7921 & \text { Calmar } \\ \text { Adj C } & -9.6 & 8630 & \text { Calmar } \\ \text { LevC } & -7.6 / 8.0 \pm 0.4 & 7756 & \text { RAP3 } \\ \text { Lev F } & -6.5 \pm 0.7 & 6766 & \text { RAP2 } \\ \text { Ref E } & -1.1 & 1001 & \text { Calmar }\end{array}$

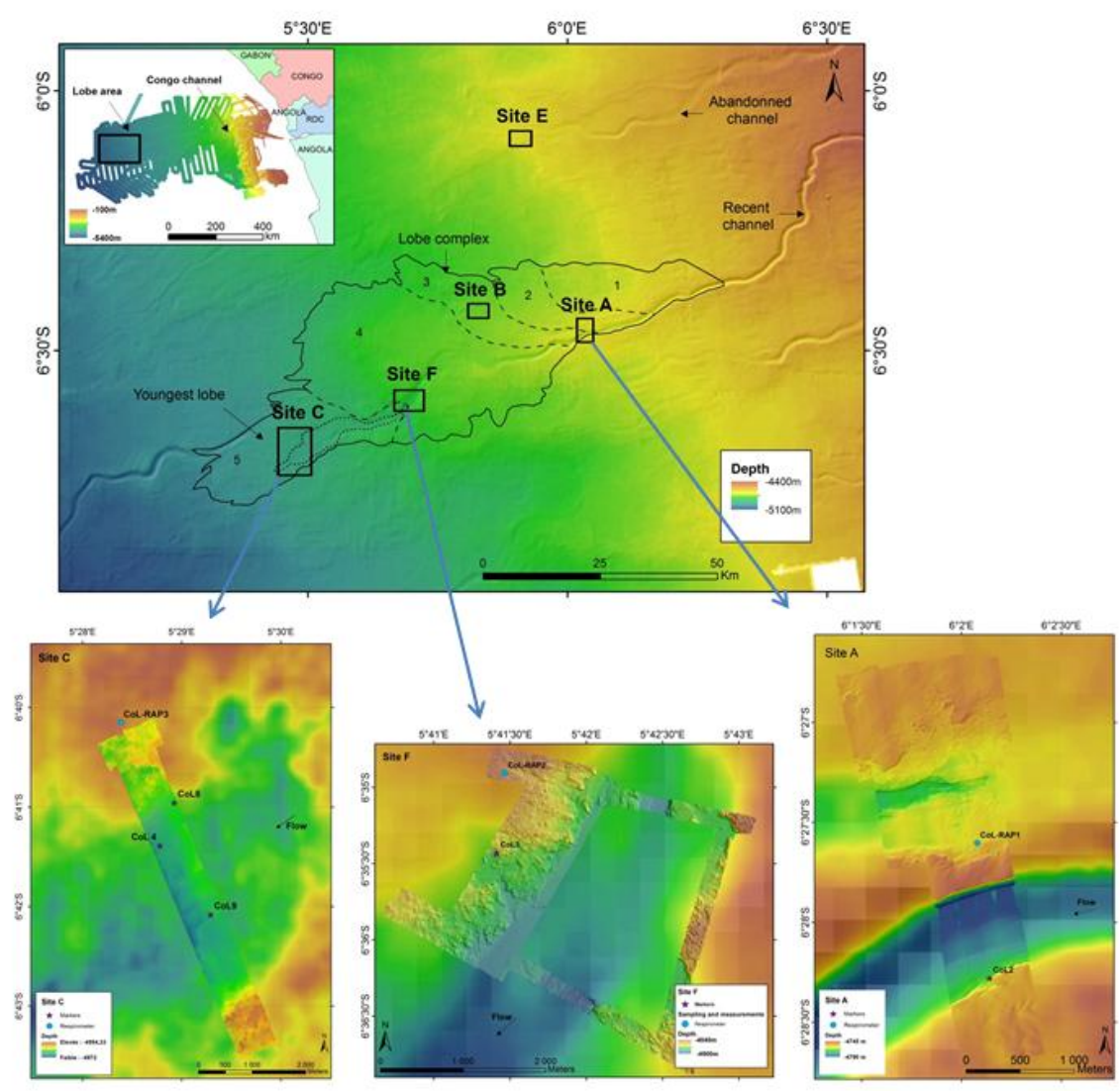


a.

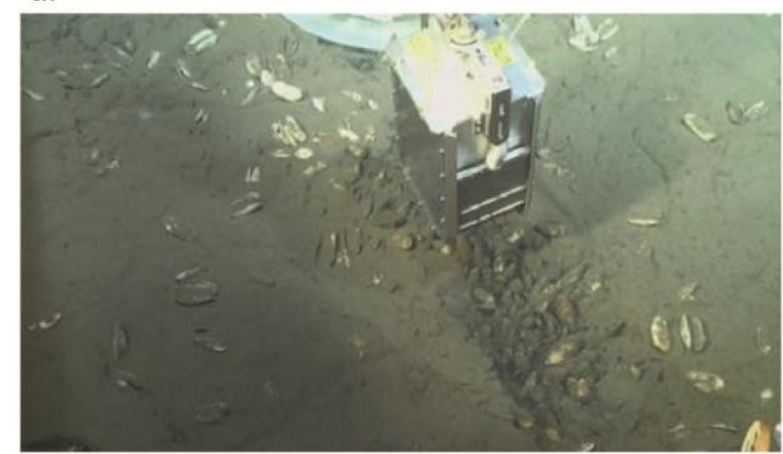

c.

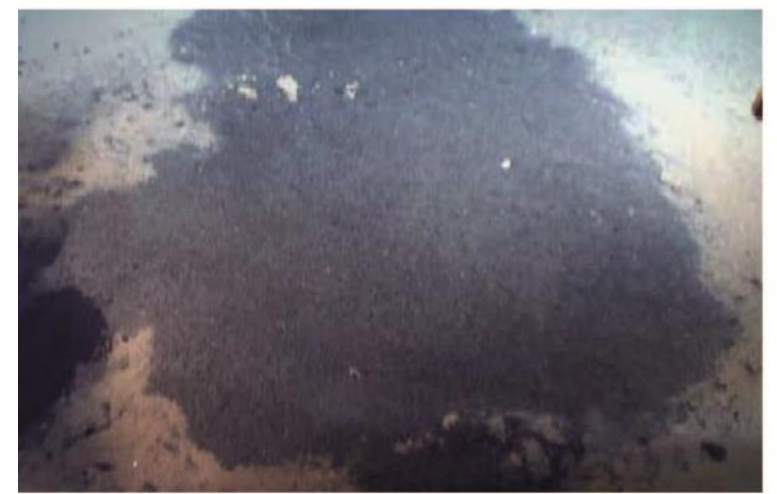

e.

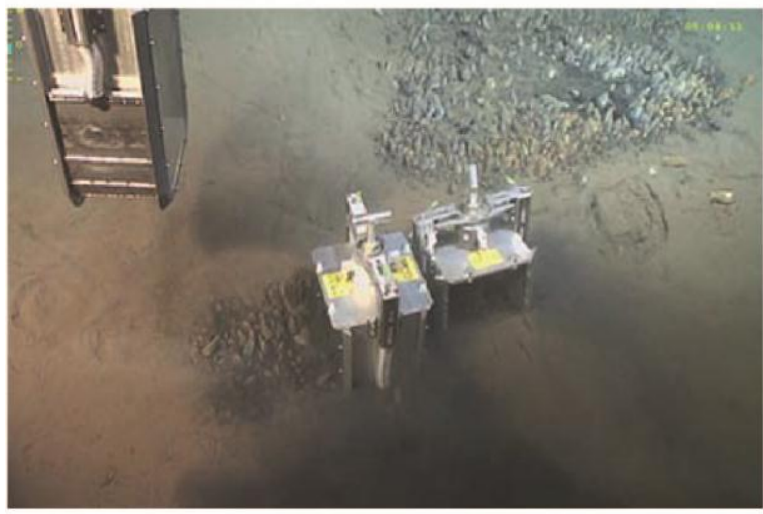

g.

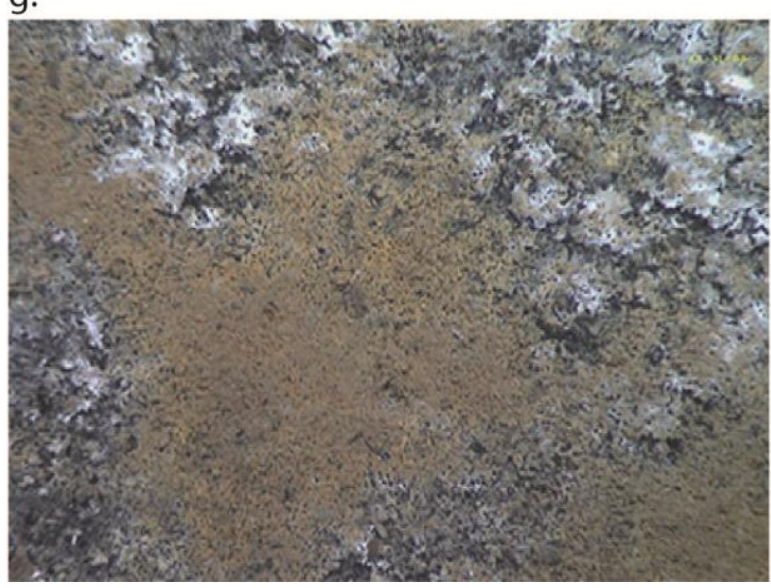

b.

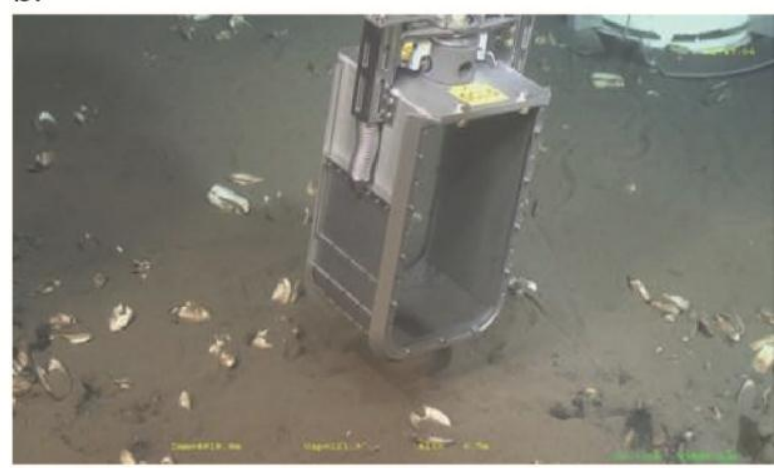

d.

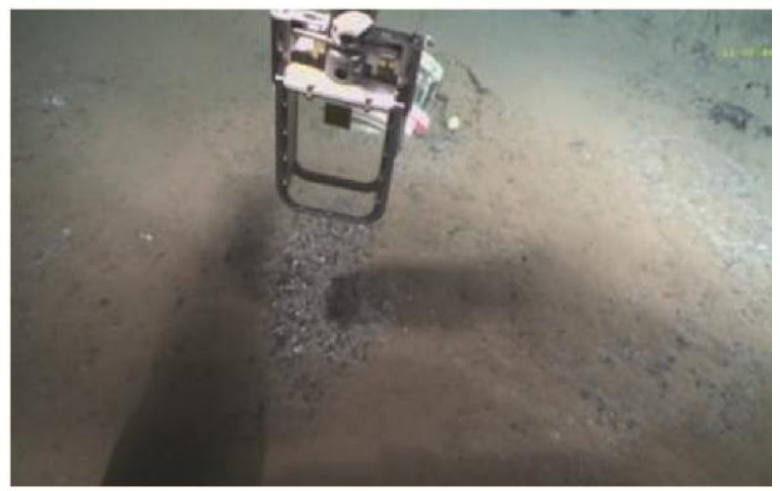

f.

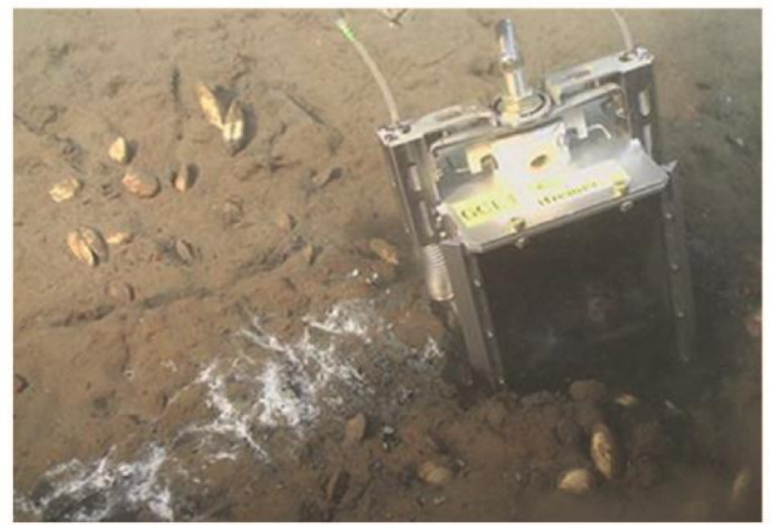

h.

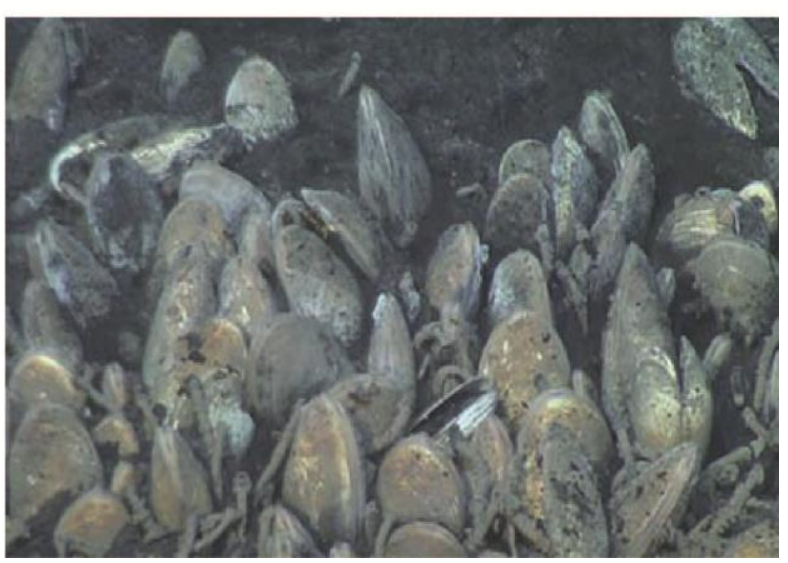



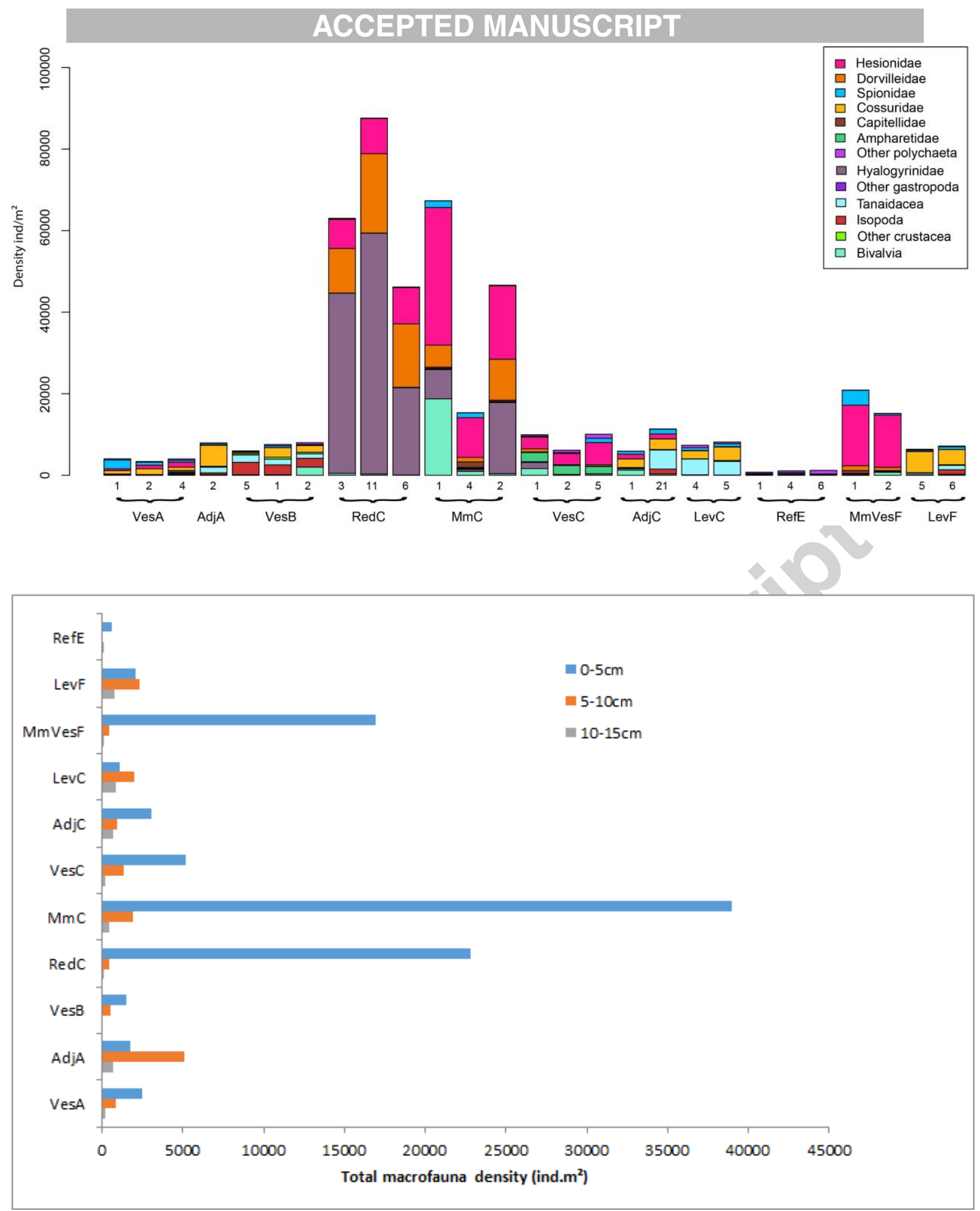


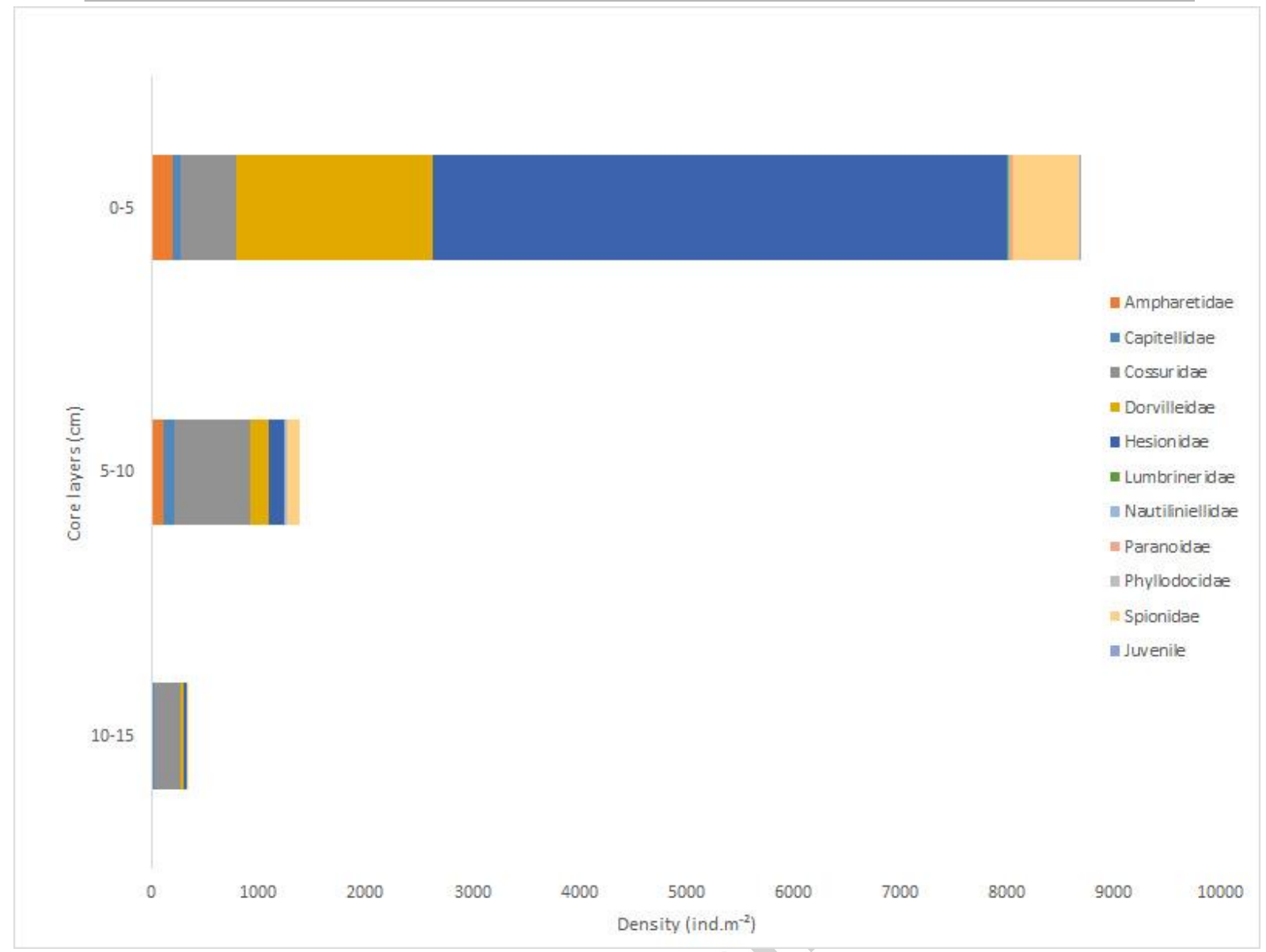



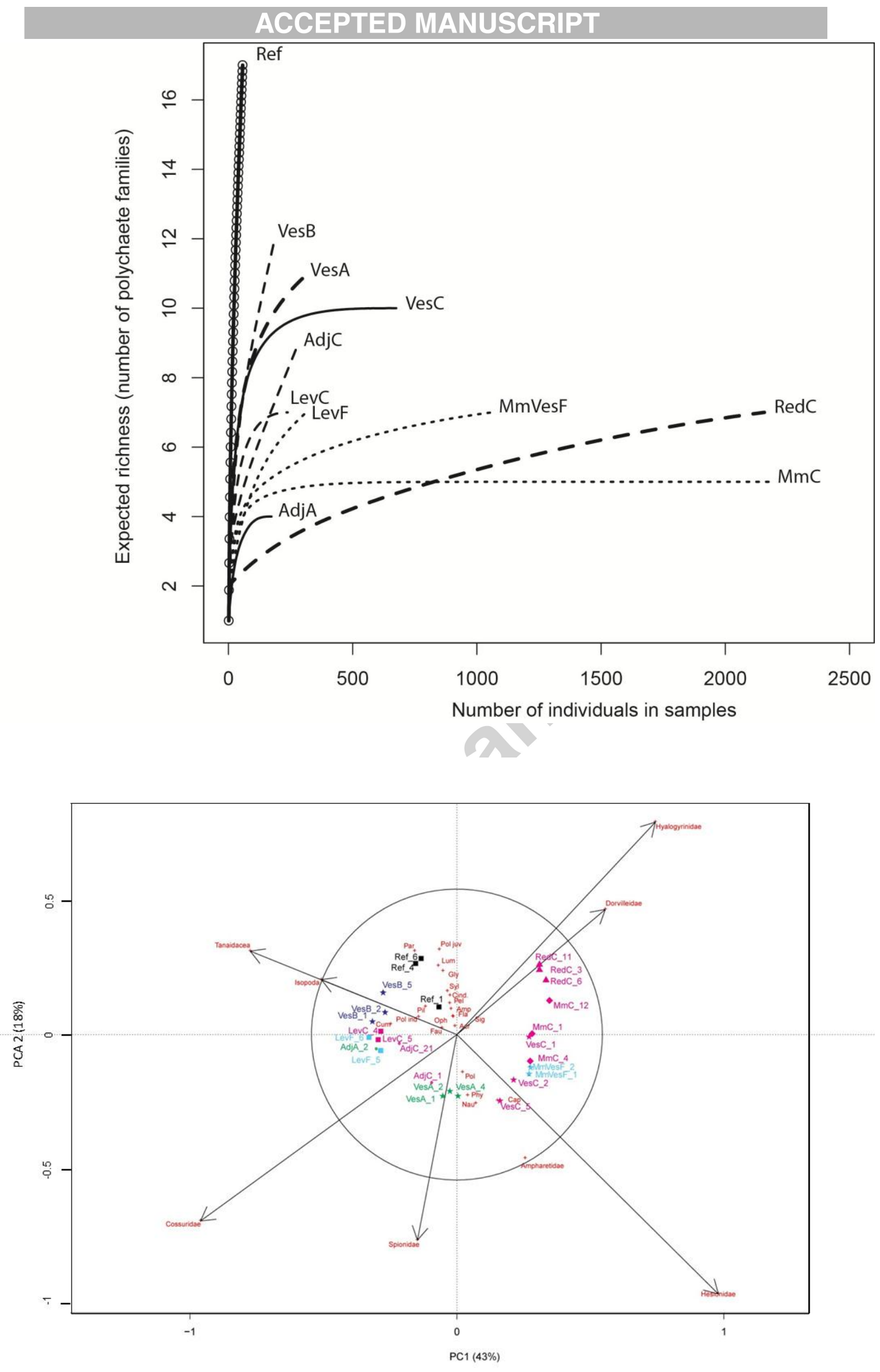


\section{ACCEPTED MANUSCRIPT}

A.

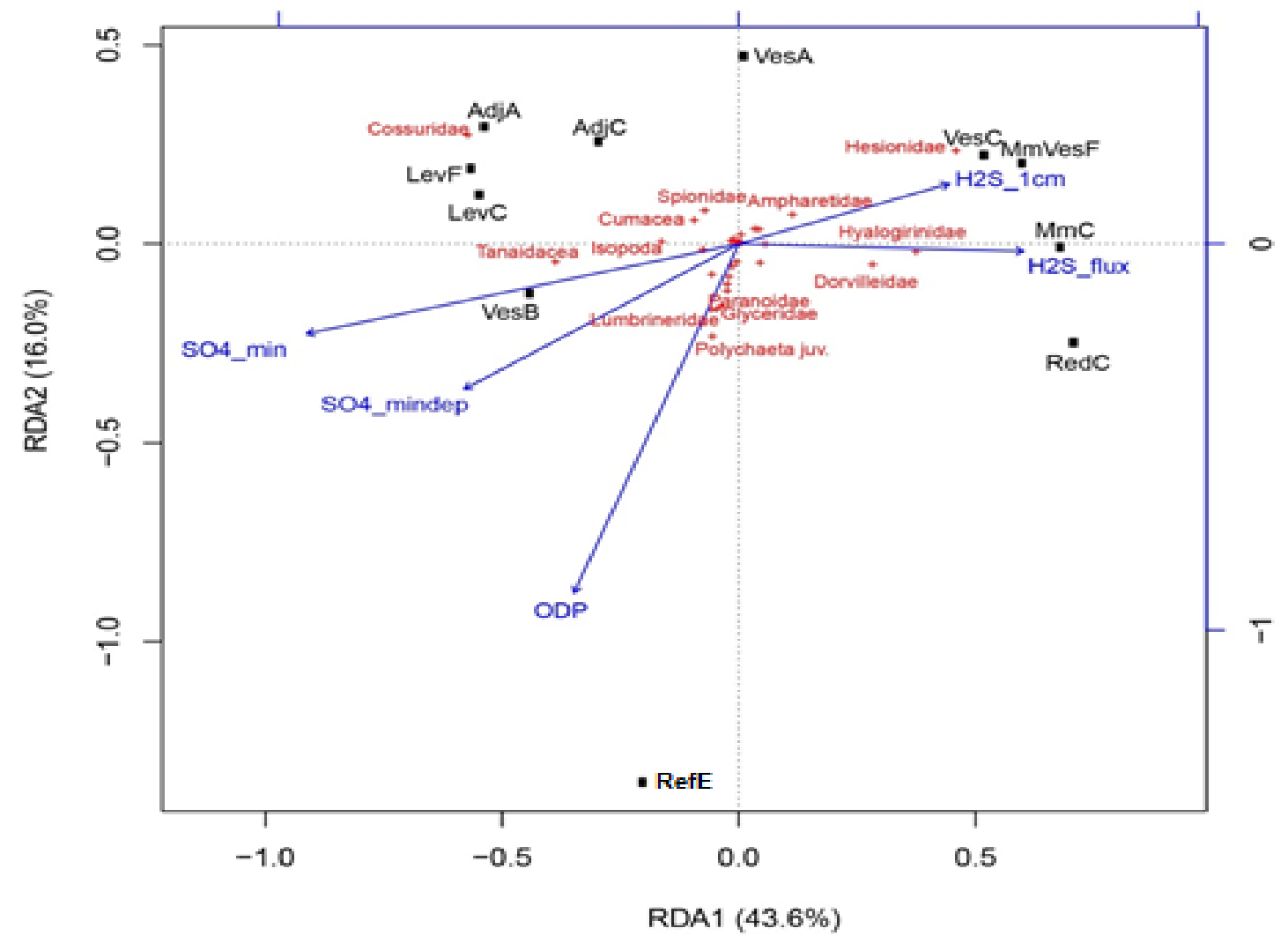

B.

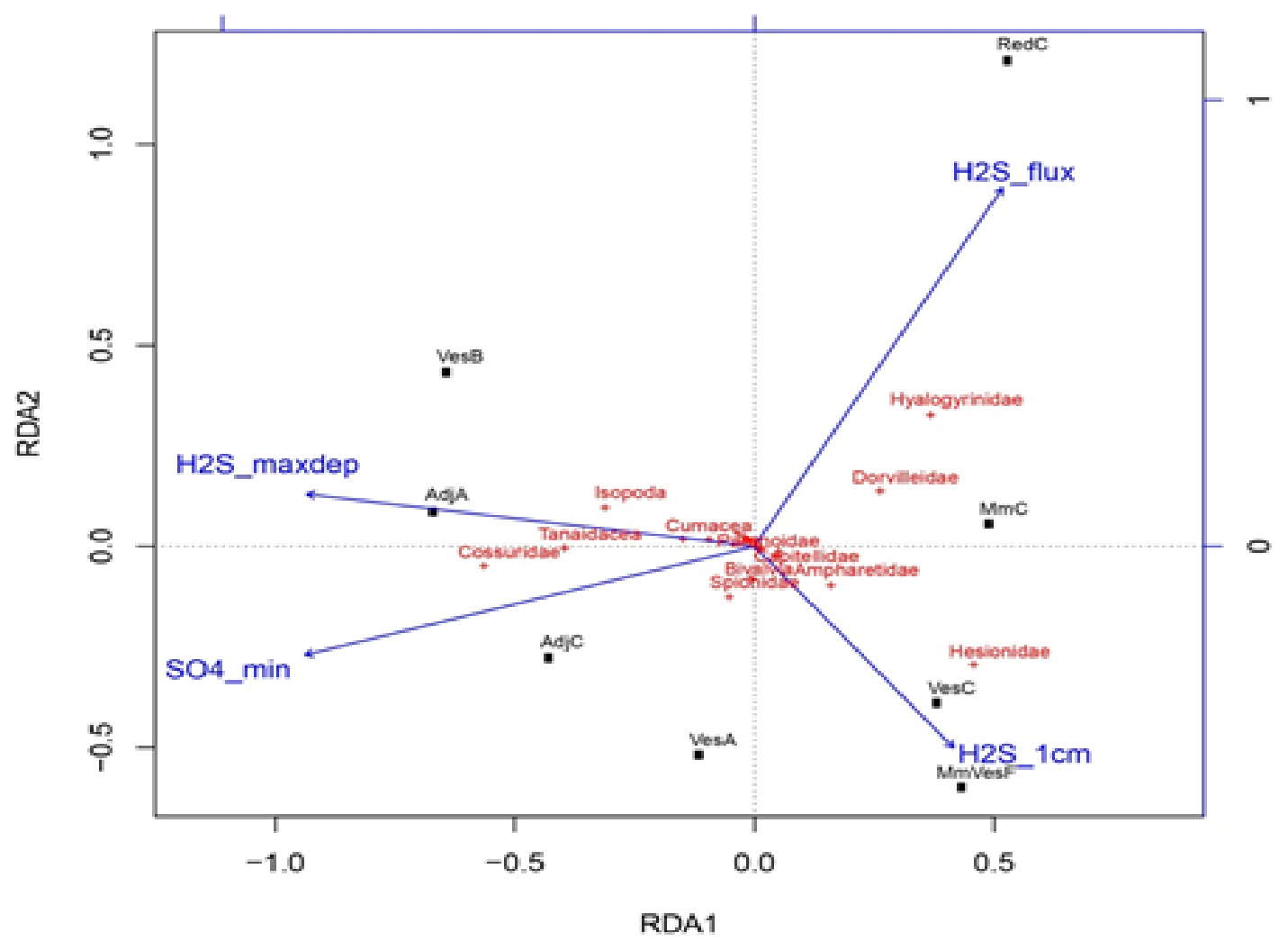




\section{ACCEPTED MANUSCRIPT}

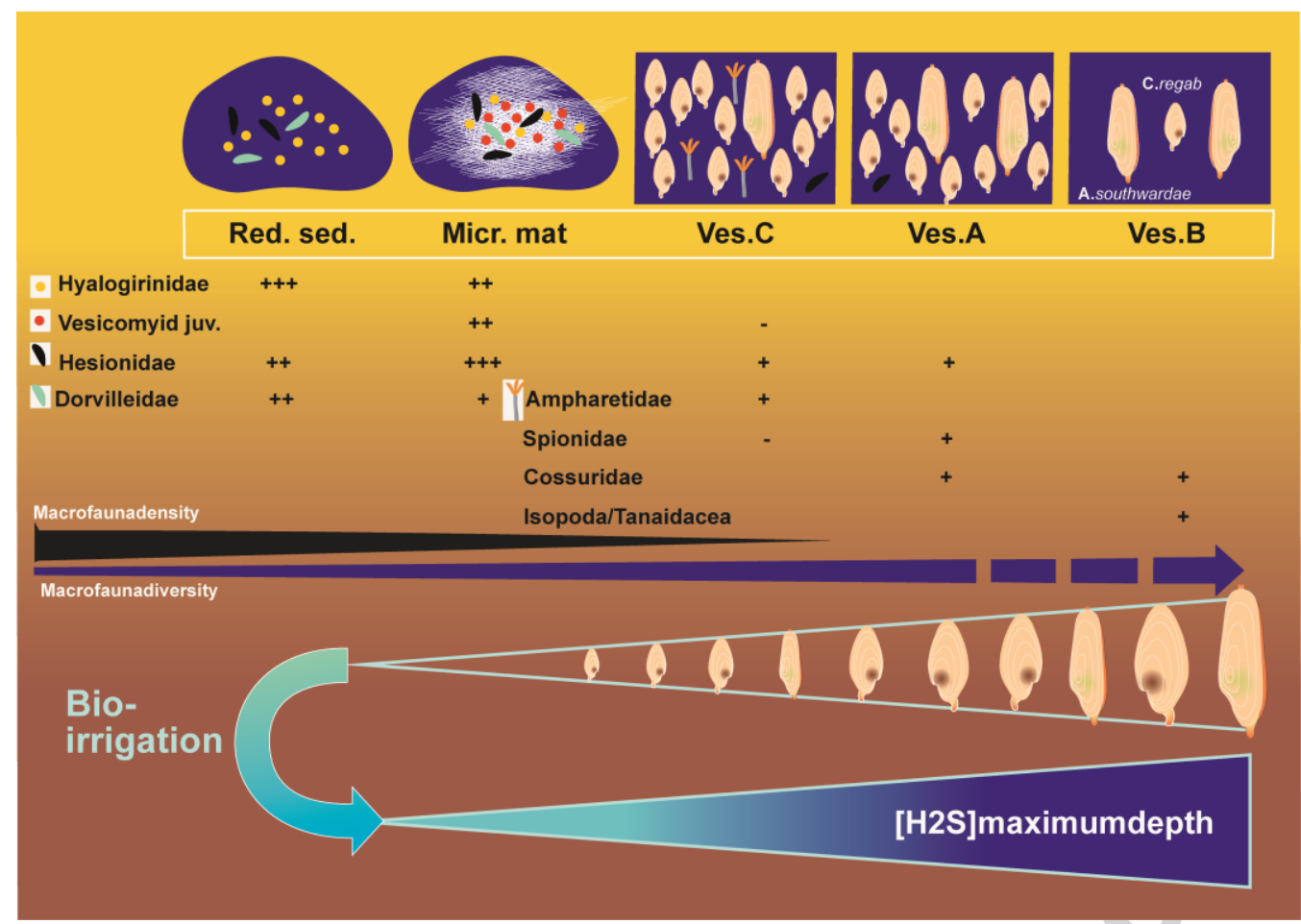

